\title{
Interannual variability of long-range transport as seen at the Mt. Bachelor observatory
}

\author{
D. R. Reidmiller ${ }^{1,2}$, D. A. Jaffe ${ }^{2}$, D. Chand ${ }^{1,2}$, S. Strode ${ }^{1, *}$, P. Swartzendruber ${ }^{1,2}$, G. M. Wolfe ${ }^{3}$, and J. A. Thornton ${ }^{1}$ \\ ${ }^{1}$ Department of Atmospheric Sciences, University of Washington, Seattle, WA, USA \\ ${ }^{2}$ Interdisciplinary Arts and Sciences, University of Washington-Bothell, Bothell, WA, USA \\ ${ }^{3}$ Department of Chemistry, University of Washington, Seattle, WA, USA \\ *now at: O'Brien \& Gere Engineers Inc. Blue Bell, PA, USA
}

Received: 30 July 2008 - Published in Atmos. Chem. Phys. Discuss.: 26 August 2008

Revised: 20 November 2008 - Accepted: 15 December 2008 - Published: 27 January 2009

\begin{abstract}
Interannual variations in background tropospheric trace gases (such as carbon monoxide, $\mathrm{CO}$ ) are largely driven by variations in emissions (especially wildfires) and transport pathways. Understanding this variability is essential to quantify the intercontinental contribution to US air quality. We investigate the interannual variability of long-range transport of Asian pollutants to the Northeast Pacific via measurements from the Mt. Bachelor Observatory (MBO: $43.98^{\circ} \mathrm{N}$, $121.69^{\circ} \mathrm{W} ; 2.7 \mathrm{~km}$ a.s.1.) and GEOS-Chem chemical transport model simulations in spring 2005 vs. the INTEX-B campaign during spring 2006. Measurements of $\mathrm{CO}$ at $\mathrm{MBO}$ were significantly enhanced during spring 2005 relative to the same time in 2006 (the INTEX-B study period); a decline in monthly mean $\mathrm{CO}$ of $41 \mathrm{ppbv}$ was observed between April 2005 and April 2006. A backtrajectory-based meteorological index shows that long-range transport of $\mathrm{CO}$ from the heavily industrialized region of East Asia was significantly greater in early spring 2005 than in 2006. In addition, spring 2005 was an anomalously strong biomass burning season in Southeast Asia. Data presented by Yurganov et al. (2008) using MOPITT satellite retrievals from this area reveal an average CO burden anomaly (referenced to March 2000February 2002 mean values) between October 2004 through April 2005 of $2.6 \mathrm{Tg}$ CO vs. 0.6 Tg CO for the same period a year later. The Naval Research Laboratory's global aerosol transport model, as well as winds from NCEP reanalysis, show that emissions from these fires were efficiently transported to MBO throughout April 2005. Asian dust transport, however, was substantially greater in 2006 than 2005, particularly in May. Monthly mean aerosol light scattering coefficient at $532 \mathrm{~nm}\left(\sigma_{s p}\right)$ at MBO more than doubled from
\end{abstract}

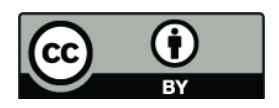

Correspondence to: D. R. Reidmiller (dreidm@atmos.washington.edu)
$2.7 \mathrm{Mm}^{-1}$ in May 2005 to $6.2 \mathrm{Mm}^{-1}$ in May 2006. We also evaluate CO interannual variability throughout the western US via Earth System Research Laboratory ground site data and throughout the Northern Hemisphere via MOPITT and TES satellite observations. Both in the Northeast Pacific and on larger scales, we reveal a significant decrease (from 2 21\%) in springtime maximum CO between 2005 and 2006, evident in all platforms and the GEOS-Chem model. We attribute this to (a) anomalously strong biomass burning in Southeast Asia during winter 2004 through spring 2005, and (b) the transport pattern in March and April 2006 which limited the inflow of Asian pollution to the lower free troposphere over western North America.

\section{Introduction}

Trans-Pacific transport of pollution from Asia is welldocumented (Jaffe et al., 1999, 2003, 2004; Bey et al., 2001; Goldstein et al., 2004; Parrish et al., 2004; Singh et al., 2009). Its effects on air quality in the downwind regions of the western US have been the focus of many recent studies (Wang et al., 2003; Akimoto, 2003). With the objective of quantifying the contribution of foreign emissions to domestic air quality throughout the Northern Hemisphere, the United Nations Economic Commission for Europe has recently established an international Task Force on Hemispheric Transport of Air Pollution (HTAP 2007).

To date, much work has been done towards understanding the processes controlling inter-continental transport. Wang et al. (2006) find that meteorology is most conducive to transPacific transport in the lower troposphere early in the spring (March and April) and in the mid- to upper-troposphere in May. Specifically, lifting ahead of southeastward-moving

Published by Copernicus Publications on behalf of the European Geosciences Union. 
cold fronts and convective transport (particularly from Southeast Asia) are the most important processes for such transport (Liu et al., 2003; Holzer and Hall, 2007). Trans-Pacific transport of pollution typically occurs on timescales of 7-10 days in the mid-troposphere. Variability of this transport has been studied on timescales ranging from days to seasons to years and even decades (Allen et al., 1996; Liang et al., 2004, 2005; Holzer and Hall, 2007; Fischer et al., 2009). We have the unique capacity to investigate the interannual variability of Asian long-range transport through continuous measurements of multiple species from the Mt. Bachelor Observatory (MBO: $43.98^{\circ} \mathrm{N}, 121.69^{\circ} \mathrm{W} ; 2.7 \mathrm{~km}$ above sea level (a.s.l.)), our free-tropospheric background site in operation since spring 2004 (Jaffe et al., 2005; Weiss-Penzias et al., 2006).

The rapid development of China over the past two decades has resulted in an increase in anthropogenic emissions (Irie et al., 2005; Richter et al., 2005). Modeling studies and satellite observations have shown that the region's development has had noticeable effects on air quality in western North America (Akimoto, 2003; Zhang et al., 2008). This pollutant burden originating in Asia has been detected at groundbased sampling stations in the western US (Jaffe et al., 2001; Weiss-Penzias et al., 2004). Jaffe and Ray (2007) found a positive trend in surface ozone $\left(\mathrm{O}_{3}\right)$ at background sites in the western US from 1987-2004. While the authors do not assign a single cause, they note that the surge in $\mathrm{O}_{3}$ precursor emissions (nonmethane-hydrocarbons and nitrogen oxides) from Asia is a likely contributor.

Motivated in part by these previous studies, the Intercontinental Chemical Transport Experiment (INTEX-B: http: //www.espo.nasa.gov/intex-b, Singh et al., 2009) took place during spring 2006 (15 April-15 May) with the objective of characterizing the pollution flowing into the West Coast of the United States, particularly from Asia. A collaborative effort among NASA, NCAR and a variety of university research groups, INTEX-B produced data from several platforms (ground-based, aircraft, remote sensing, model, etc.). Among these was the University of Washington's Duchess aircraft which flew seven flights off the coast of Washington state; results from this analysis are presented by Swartzendruber et al. (2008). Through an investigation of transPacific transport pathways, INTEX-B provided an opportunity to better understand the meteorological aspects of interannual variability in trace gases. Of particular interest during INTEX-B was the transport of Asian emissions to western North America.

Carbon monoxide (CO) is produced anthropogenically by the incomplete combustion of fossil fuels as well as by intentional biomass burning for agricultural purposes. It is also emitted naturally through wildfires and is a byproduct of the oxidation of methane and other hydrocarbons. With a tropospheric lifetime on the order of several weeks to months (depending largely on latitude and season) and relatively simple chemistry, an investigation of the spatiotemporal variability of $\mathrm{CO}$ allows a study into the relative influences of source regions, meteorology and chemical loss on its global distribution (Novelli et al., 1998; Holloway et al., 2000). Interannual variability in $\mathrm{CO}$ is controlled by changes in emissions (particularly wildfires), transport pathways and the oxidizing capacity of the troposphere.

Many studies of the spatial and temporal variability of $\mathrm{CO}$ in the north Pacific exist, but as Granier et al. (1996) and others note, year-to-year variations in $\mathrm{CO}$ abundances are not well established. Holloway et al. (2000) examine how the three major sources of $\mathrm{CO}$ (fossil fuel combustion, biomass burning and oxidation of biogenic hydrocarbons and $\mathrm{CH}_{4}$ ), as well as its main sink (reaction with $\mathrm{OH}$ ), vary seasonally and globally. Khalil and Rasmussen (1988) detected a positive trend in global CO of $0.8-1.4 \% / y r$ during the $1980 \mathrm{~s}$, which they attributed to increasing anthropogenic emissions. Several years later the same authors (Khalil and Rasmussen, 1994) reported a global decrease in tropospheric CO concentrations of $-2.6 \% / \mathrm{yr}$ during the late $1980 \mathrm{~s}$ and into the early 1990s. The authors attributed this trend to decreasing anthropogenic emissions in the Northern Hemisphere (mainly from pollution controls in North America and Europe) and potentially decreasing tropical biomass burning emissions in the Southern Hemisphere. These studies exemplify the need for caution in reading too much into the existence of "trends" in $\mathrm{CO}$ and highlight the need to understand the highly variable interannual changes in $\mathrm{CO}$.

Recently, Szopa et al. (2007) utilized surface measurements and model results from 1997-2001 to quantify the relative contributions of biomass burning emissions and meteorology to interannual variations in $\mathrm{CO}$ concentrations. They found that, at latitudes greater than $\sim 60^{\circ}$, CO interannual variability is controlled almost equally by variations in wildfire emissions and meteorology, whereas meteorological variability dominates in the tropics. The exception to this appears to be during specific episodes, such as El Niño periods, which are typically associated with intense tropical biomass burning that can drive large interannual changes in CO concentrations globally. Notably, though, El Niño periods are also associated with altered transport patterns such as the reversing of trade winds which can lead to the westward export of Indonesian wildfires. At one site in Wendover, UT (39.9 $9^{\circ}$ N, $113.72^{\circ} \mathrm{W} ; 1320 \mathrm{~m}$ a.s.1.), Szopa et al. (2007) show that from 1997-2001 biomass burning emissions contribute $25-51 \%$ to modeled CO interannual variability.

The focus of this paper is on the interannual variability of long-range transport of East Asian pollution (particularly $\mathrm{CO}$ ) to the Northeast Pacific between spring 2005 and spring 2006. We analyze measurements recorded at MBO during the spring seasons of 2005 and 2006, which includes the INTEX-B study period. Our analysis focuses on the decrease in CO from spring 2005 to spring 2006 observed at MBO as well as in MOPITT and TES satellite observations. The GEOS-Chem 3-D chemical transport model is employed using constant, climatological emissions to understand the 
meteorological contribution to this change. A comparison of trace gas measurements made at $\mathrm{MBO}$ during spring 2005 and 2006 reinforce the findings from the $\mathrm{CO}$ analysis. We then utilize the Asian long-range transport index developed by Wolfe et al. (2007) to show that emissions from East Asia had a greater effect on lower tropospheric air quality in the northwestern US in early spring 2005 than in early spring 2006. Finally, we extend the analysis of $\mathrm{CO}$ variability between 2005 and 2006 to the broader western US (using Earth System Research Laboratory (ESRL) ground site data), and throughout the Northern Hemisphere via MOPITT and TES satellite retrievals to show that wildfire activity also played a role in the observed changes in $\mathrm{CO}$.

\section{Instrumentation and methodology}

\subsection{Mt. Bachelor site and instrumentation}

The MBO site (Fig. 1: $43.98^{\circ} \mathrm{N}, 121.69^{\circ} \mathrm{W} ; 2.7 \mathrm{~km}$ a.s.l.) has been described in detail elsewhere (Jaffe et al., 2005; Weiss-Penzias et al., 2006, 2007; Swartzendruber et al., 2006; Wolfe et al., 2007). In brief, Mt. Bachelor is an isolated volcanic peak located in the Deschutes National (coniferous) Forest and is home to a ski resort on the east face of the mountain. The nearest populated areas are Bend (pop. 65210 ), $31 \mathrm{~km}$ to the east and Redmond (pop. 21 109), which is $53 \mathrm{~km}$ northeast of MBO. Winds at the summit usually have a strong westerly component, so it is rare that anthropogenic pollution from either town reaches the station. Eugene (pop. 142180) is mainly a university-town located $140 \mathrm{~km}$ west of MBO and is the only major population center between MBO and the Pacific coast. Instrumentation is housed in the ski lift building on the mountain's summit. The lift itself is electric; the only emissions at the summit are due to the occasional passes of snow-grooming equipment. Contamination from these groomers is easily identified by spikes in $\mathrm{NO}_{\mathrm{x}}, \mathrm{CO}$ and aerosol scattering coefficient and has been screened out for our analysis.

The sampling inlet line for gaseous measurements is $5 / 8^{\prime \prime}$ OD PFA tubing and is located $\sim 15 \mathrm{~m}$ above the instrument room and $4 \mathrm{~m}$ above the roof of the building. Ambient air is drawn through a $1 \mu \mathrm{m}$ Teflon filter and into a gas distribution manifold at a rate of $\sim 20 \mathrm{slpm}$. All trace gas measurement systems are connected to this manifold, except the $\mathrm{Hg}$ instrumentation, which has its own specially-designed inlet (Swartzendruber et al., 2006). Basic meteorological measurements (temperature, relative humidity $(\mathrm{RH})$, ambient pressure, wind speed and direction) are collected near the inlet. Water vapor has been calculated using ambient temperature and RH measured from a Campbell Scientific HMP $45 \mathrm{C}$ probe that is calibrated every six months. Beginning 26 April 2006, a second Campbell Scientific HMP 45 C probe was installed in an area that is sheltered, but still exposed to ambient conditions, to obtain measurements from a probe

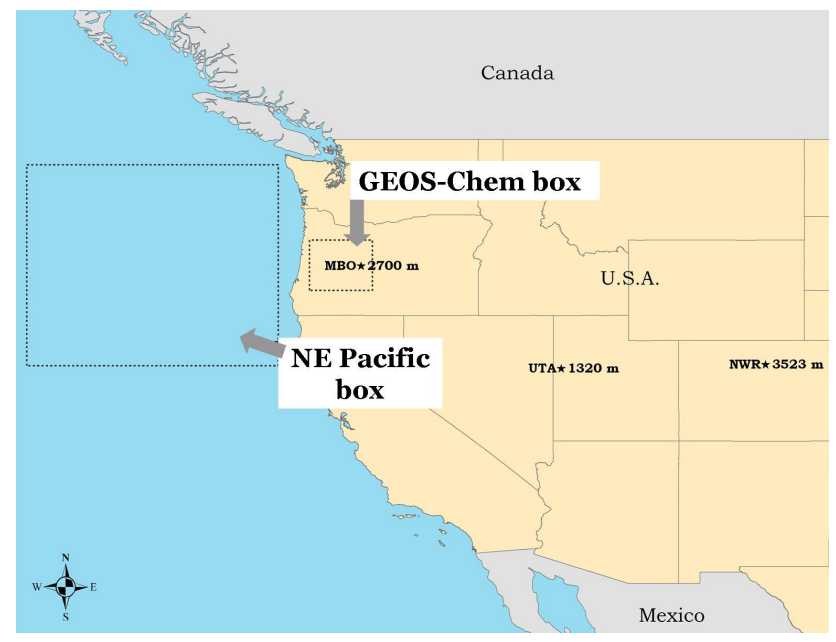

Fig. 1. Map of the western US illustrating the location and altitude of MBO and the two ESRL ground sites used in the analysis, as well as placement of the box employed for GEOS-Chem analysis. The "NE Pacific box" denotes the region used for MOPITT and TES satellite retrievals.

that was not as susceptible to riming. A Licor 6262 (calibrated every six months) also measured water vapor until 1 April 2006. CO was measured using a TECO 48 C-TL nondispersive infrared instrument. It was zeroed every $20 \mathrm{~min}$ and calibrated daily using a working standard that was referenced to three standard reference gases (provided by ESRL in Boulder, CO, NIST and Scott-Specialty Gases). During INTEX-B, the same standard reference gas was used at MBO and on the Duchess aircraft (Swartzendruber et al., 2008). Comparisons between MBO and Duchess CO calibrations agreed within 1-2\% (P. Swartzendruber and D. Jaffe, unpublished work). $\mathrm{O}_{3}$ was measured with an UV absorption instrument (Dasibi, Inc.). It was calibrated quarter-annually with an $\mathrm{O}_{3}$ transfer standard referenced to a State of Washington primary $\mathrm{O}_{3}$ standard. Sub-micron aerosol scattering coefficient at $532 \mathrm{~nm}\left(\sigma_{s p}\right)$ was measured with a Radiance Research integrating nephelometer through its own inlet of nonconductive tubing. It was calibrated quarterly with pure $\mathrm{CO}_{2}$ gas. The $\sigma_{s p}$ data in this paper are presented at ambient pressure and temperature. Total airborne mercury (THg) was measured from March 2004-March 2005. Thereafter, a speciation component was added, allowing separate measurements of elemental mercury $\left(\mathrm{Hg}^{0}\right)$, particulate mercury $(\mathrm{PHg})$ and reactive gaseous mercury (RGM). Instrumental design and specifications for the $\mathrm{Hg}$ measurements at MBO are discussed at length in Swartzendruber et al. (2006). During INTEX-B acyl peroxy nitrates (APNs) were measured at MBO using a custom-built thermal dissociation chemical ionization mass spectrometer, or TD-CIMS (Wolfe et al., 2007). The $1 \sigma$ uncertainty for the hourly-averaged data was: $1 \%$ for $\mathrm{CO}, 1 \%$ for $\mathrm{O}_{3}, 5 \%$ for $\sigma_{s p}$, and $1 \%$ for $\mathrm{Hg}$. 


\subsection{GEOS-Chem model description}

The GEOS-Chem 3-D global chemical transport model (http: //www-as.harvard.edu/chemistry/trop/geos; Bey et al., 2001) is driven by assimilated meteorological data compiled at the Goddard Earth Observing System (GEOS) of the NASA Global Modeling and Assimilation Office (GMAO), which include winds, temperature, surface pressure, water content, clouds, precipitation, convective mass fluxes, mixed layer depth and surface properties. It has been used extensively in chemical transport studies in the Northeast Pacific (Liu et al., 2003; Goldstein et al., 2004; Liang et al., 2004, 2005; Wang et al., 2006; Auvray et al., 2007; Zhang et al., 2008) and at MBO (Weiss-Penzias et al., 2004; Swartzendruber et al., 2006; Liang et al., 2007). Model output (version 7.04.05) has been compared with mean $\mathrm{CO}$ measurements from $\mathrm{MBO}$ using data with a resolution of $1 \mathrm{~h}$. Results were obtained for the $2^{\circ} \times 2.5^{\circ}$ box covering $43-45^{\circ} \mathrm{N}, 121.25-123.75^{\circ} \mathrm{W}$ around MBO (Fig. 1).

The GEOS-Chem model calculates mixing ratios for 55 vertical layers, or "sigma-levels". The atmospheric pressure of these sigma-levels varies depending upon the underlying topography and elevation above sea level. Sigma-levels 5 through 7 (i.e., pressure levels from $746 \mathrm{hPa}-574 \mathrm{hPa}$ ) best match the observed $\mathrm{CO}$ values at $\mathrm{MBO}$ for most meteorological conditions and/or seasons. Therefore, we have averaged the results from sigma-levels 5-7 for our analysis.

The model was run using monthly archived $\mathrm{OH}$ fields, as well as climatological, monthly varying anthropogenic emissions scaled to 1998 using the approach described by Bey et al. (2001) and biomass burning emissions from 1996-2000 (Duncan et al., 2003). Using constant, climatological emissions allows us to analyze the role meteorology played in the interannual variability of $\mathrm{CO}$. Tagged Asian fossil fuel $\mathrm{CO}$ emissions were output for the box bounded by $65-146^{\circ} \mathrm{E}$, $9^{\circ} \mathrm{S}-90^{\circ} \mathrm{N}$, and tagged Asian biomass burning $\mathrm{CO}$ emissions were constrained to the region covering $65-146^{\circ} \mathrm{E}$, $9^{\circ} \mathrm{S}-45^{\circ} \mathrm{N}$. The model comparison with $\mathrm{MBO}$ and its implications are discussed in more detail in Sect. 4.2.

\subsection{MOPITT and TES satellite descriptions}

Carbon monoxide in the troposphere is routinely retrieved from thermal infrared measurements by the Tropospheric Emissions Spectrometer (TES; Beer et al., 2001) and Measurements of Pollution in the Troposphere (MOPITT; Drummond and Mand, 1996) instruments on-board the Aura and Terra satellites launched in July 2004 and December 1999, respectively. MOPITT CO products have been evaluated by comparisons to aircraft and ground-based measurements (Emmons et al., 2004, 2007; Warner et al., 2007). Emmons et al. (2004) show a good overall quantitative agreement between MOPITT and in situ profiles with a small average positive bias (i.e., MOPITT senses larger values) at all altitudes. The standard deviation of the mean biases is large, however, particularly for the lower troposphere $(\sim 20 \%)$. The large positive biases tend to be seen most frequently in clean environments, such as the remote oceans. Emmons et al. (2007) find that, over North America at $700 \mathrm{hPa}$, MOPITT has a bias of 9-17 ppbv when compared to in situ profiles, which is consistent with Emmons et al. (2004) and within the design criteria for $10 \%$ accuracy. Warner et al. (2007) also find a positive bias in MOPITT of 15-20 ppbv in the lower atmosphere over the oceans as part of evaluation exercises during the INTEXA campaign. Similar evaluation exercises have been carried out for TES retrievals, though they are fewer in number (Osterman et al., 2005; Luo et al., 2007a). Luo et al. (2007a) compare TES profiles (which are most sensitive to $\mathrm{CO}$ between $\sim 700-200 \mathrm{hPa}$ ) to aircraft profiles (performed from the surface to $\sim 300 \mathrm{hPa}$ ) during INTEX-B and find good agreement over the Houston area, with TES detecting $\mathrm{CO}$ mixing ratios that are only $0-10 \%$ less than the aircraft profiles. Validation efforts were not as successful near Hawaii and over Anchorage, Alaska, where long-range transport of pollution created well-defined plumes that the aircraft specifically flew into but TES may not have passed over. These latter attempts exemplify the challenging nature of obtaining good comparisons between satellites and aircraft. Luo et al. (2007b) show how different TES and MOPITT retrievals can be from each other, but present techniques to bring the retrieved profiles into better agreement (such as adjusting the TES profiles to the MOPITT a priori and vertically smoothing the MOPITT profiles by the TES averaging kernels).

The retrieved profile from each platform is a linear combination of the averaging kernel-weighted true and a priori profiles in conjunction with retrieval errors (Luo et al., 2007a, b). There are significant differences in the a priori profile and covariance matrix constraints for TES retrievals and those adopted by MOPITT; these are described by $\mathrm{Ku}-$ lawik et al. (2006) and Deeter et al. (2003), respectively. In brief, the main difference is that TES CO retrievals select a priori profiles given by the MOZART chemical transport model (Brasseur et al., 1998). Monthly mean mixing ratios in $10^{\circ}$ latitude by $60^{\circ}$ longitude bins are used to create the a priori profiles assumed for TES retrievals (Rinsland et al., 2006). In contrast, MOPITT uses a single $\mathrm{CO}$ a priori profile derived from several hundred in situ profiles distributed globally (Deeter et al., 2003).

In our analysis, we calculated monthly mean $\mathrm{CO}$ from MOPITT and TES using only daytime data, as several studies have shown that nighttime satellite data tends to have larger biases due to weaker thermal gradients in the vertical (Emmons et al., 2004, 2007). In general, daytime observations should produce better thermal contrast conditions between the surface and lower troposphere because of surface heating due to the absorption of solar radiation (Deeter et al., 2007). The averaging kernels for both TES and MOPITT throughout the lower troposphere are very similar, indicating that the $\mathrm{CO}$ information in the retrievals comes mainly from the $700-500 \mathrm{hPa}$ layer, with some additional information in 
the upper troposphere (Emmons et al., 2007). As a result, we present daytime-only, lower- to mid-tropospheric results. These vertical levels also correspond fairly well with the free-tropospheric altitude of $\mathrm{MBO}(\sim 730 \mathrm{hPa})$. We use retrievals from a regional box over the Northeast Pacific Ocean (Fig. 1: $40^{\circ}-48^{\circ} \mathrm{N}, 125^{\circ}-135^{\circ} \mathrm{W}$ ) for our analysis since this provides a measure of $\mathrm{CO}$ without impacts from topography (causing changes in column density) and variable surface temperature and emissivity. This is the first time monthly mean L3 TES data products have been published (courtesy of M. Luo and G. Osterman, 2007).

\subsection{Meteorological index of long-range transport}

To assess the relative degree of trans-Pacific transport of Asian pollution to $\mathrm{MBO}$, we employ the Asian long-range transport (ALRT) index developed by Wolfe et al. (2007). It uses 10-day kinematic backtrajectories calculated from the Hybrid Single-Particle Lagrangian Integrated Trajectory (HYSPLIT) model (Draxler and Rolph, 2003; http://www. arl.noaa.gov/ready/hysp_info.html). The model was run with FNL meteorological data (Final Global Data Assimilation System), which has a $6 \mathrm{~h}$ temporal resolution, $191 \mathrm{~km}^{2}$ horizontal resolution and vertical information from 13 pressure levels ranging from 1000 to $20 \mathrm{hPa}$. While the GDAS dataset has greater vertical and temporal resolution, significant gaps exist in the GDAS data for the periods of interest in this study. Twenty-five backtrajectories are calculated in a $0.5^{\circ}$ by $0.5^{\circ}$ horizontal grid at $100 \mathrm{~m}$ vertical intervals from 0 to $2900 \mathrm{~m}$ above ground level (a.g.l.) for every hour of the study period (1 March-31 May of 2005 and 2006). The number of hours each backtrajectory particle spends in the Asian boundary layer (bounded by: $0-3 \mathrm{~km}$ and $20-45^{\circ} \mathrm{N}$ by $100-130^{\circ} \mathrm{E}$, which covers the heavily developed and industrial region of east-central China and Korea) is counted and then averaged over the 25 backtrajectories for that initialization time and altitude. Thus, an "ALRT Index" value of $20 \mathrm{~h}$ could be interpreted to mean that an "average" backtrajectory particle spent $20 \mathrm{~h}$ in the boundary layer of the Asian box before transport to MBO. This method, and techniques very similar to the one presented here, have been used successfully in several studies (Stohl et al., 2002; Weiss-Penzias et al., 2004, 2006, 2007; Hafner et al., 2007; Wolfe et al., 2008). The reader is referred to Weiss-Penzias et al. (2006) and Wolfe et al. (2007) for more details on the development of this index and its use in analysis of trace gas observations.

\section{INTEX-B results from $\mathrm{MBO}$}

Table 1 summarizes basic statistics for 1 March-31 May of 2005 and 2006 for a variety of chemical species and meteorological parameters at MBO. We compare the results from the two spring seasons in the next section. Here, we briefly summarize the findings in spring 2006, the INTEX-B study
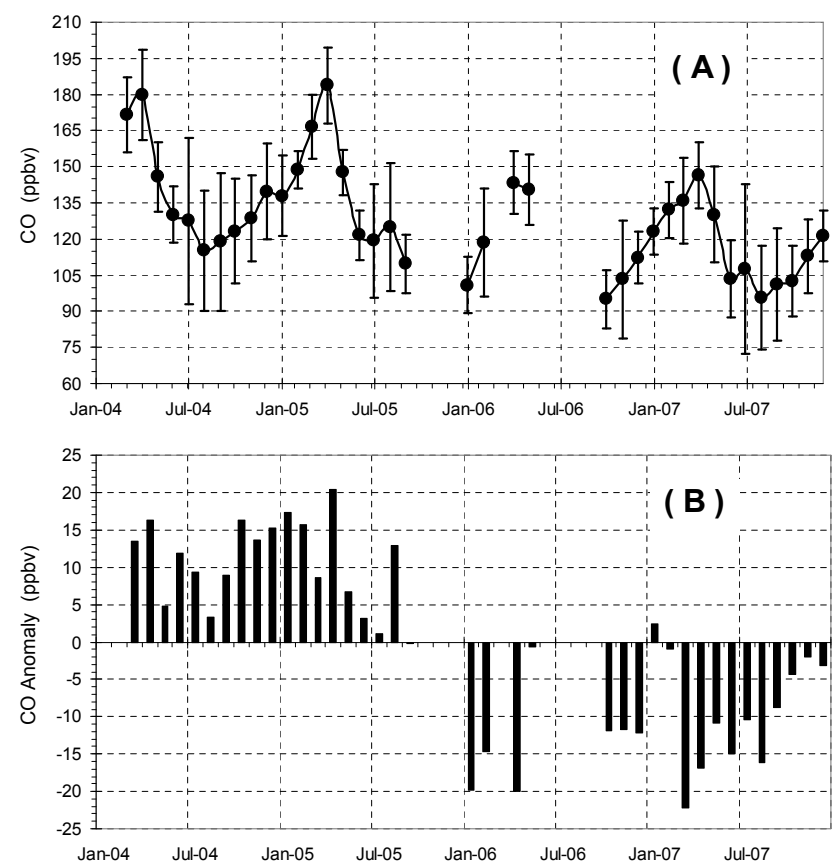

Fig. 2. (A) Monthly mean $\mathrm{CO}$ values as measured at the Mt. Bachelor Observatory (MBO); error bars represent $1 \sigma$. (B) Monthly CO anomalies referenced to average monthly $\mathrm{CO}$ for the entire 20042007 timeseries.

period. Ozone is significantly different between the driest and wettest $1 / 3$ of data. This is to be expected as dry air is typically associated with descending free tropospheric (FT) air which is rich in $\mathrm{O}_{3}$. In contrast, the wetter boundary layer (BL)-influenced air shows smaller $\mathrm{O}_{3}$ concentrations reflecting the strength of regional deposition as well as the scarcity of $\mathrm{O}_{3}$ precursors (e.g., $\mathrm{NO}_{\mathrm{x}}=\mathrm{NO}+\mathrm{NO}_{2}$ ) sources in the area. The other significant difference between the dry and wet data can be seen in measurements of $\mathrm{Hg}$ species. Swartzendruber et al. (2006) found that elemental $\mathrm{Hg}\left(\mathrm{Hg}^{0}\right)$ and reactive gaseous Hg (RGM) are anticorrelated, with RGM showing significant enhancements in subsiding FT air. RGM shows wide variability ( $1 \sigma>100 \%$ of the mean), indicating a small number of significant enhancements create a non-normal distribution of the data. Wolfe et al. (2007) also found significant enhancements of acyl peroxy nitrates (APNs) in drier, FT air relative to BL-influenced air at MBO during INTEXB. In general, $\mathrm{CO}, \mathrm{O}_{3}$ and $\sigma_{s p}$ values are similar to measurements from other western US background sites (Jaffe et al., 1999, 2001; Goldstein et al., 2004; Weiss-Penzias et al., 2004). 
Table 1. Statistics from hourly data at MBO from 1 March-31 May of 2005 and 2006. The "driest 1/3 of data" represents data concurrent with the lowest $1 / 3$ (33rd percentile) of measured water vapor, whereas the "wettest $1 / 3$ of data" represents data concurrent with the highest $1 / 3$ (67th percentile) of measured water vapor.

\begin{tabular}{|c|c|c|c|c|c|c|c|c|c|c|c|c|}
\hline \multirow{3}{*}{$\begin{array}{l}1 \text { Mar- } \\
31 \text { May }\end{array}$} & \multicolumn{4}{|c|}{ ALL Data } & \multicolumn{4}{|c|}{ DRIEST $1 / 3$ of data } & \multicolumn{4}{|c|}{ WETTEST $1 / 3$ of data } \\
\hline & \multicolumn{2}{|c|}{2005} & \multicolumn{2}{|c|}{2006} & \multicolumn{2}{|c|}{2005} & \multicolumn{2}{|c|}{2006} & \multicolumn{2}{|c|}{2005} & \multicolumn{2}{|c|}{2006} \\
\hline & Mean $\pm 1 \sigma$ & Median & Mean $\pm 1 \sigma$ & Median & Mean $\pm 1 \sigma$ & Median & Mean $\pm 1 \sigma$ & Median & Mean $\pm 1 \sigma$ & Median & Mean $\pm 1 \sigma$ & Median \\
\hline WV (g/kg) & $3.12 \pm 0.99$ & 3.13 & $2.53 \pm 0.87$ & 2.51 & $2.04 \pm 0.52$ & 2.20 & $1.60 \pm 0.46$ & 1.71 & $4.16 \pm 0.54$ & 4.06 & $3.48 \pm 0.51$ & 3.36 \\
\hline $\mathrm{CO}$ (ppbv) & $167 \pm 20$ & 165 & $142 \pm 14$ & 144 & $174 \pm 20$ & 175 & $143 \pm 13$ & 143 & $158 \pm 15$ & 157 & $137 \pm 17$ & 138 \\
\hline $\mathrm{O}_{3}(\mathrm{ppbv})$ & $48.1 \pm 6.7$ & 47.6 & $49.0 \pm 8.2$ & 48.4 & $51.8 \pm 6.5$ & 50.4 & $53.6 \pm 8.7$ & 50.4 & $44.5 \pm 6.3$ & 44.7 & $44.4 \pm 7.7$ & 46.5 \\
\hline $\mathrm{Hg}^{0}\left(\mathrm{ng} / \mathrm{m}^{3}\right)$ & $1.65 \pm 0.16$ & 1.66 & $1.67 \pm 0.15$ & 1.66 & $1.51 \pm 0.26$ & 1.46 & $1.74 \pm 0.12$ & 1.72 & $1.68 \pm 0.14$ & 1.68 & $1.65 \pm 0.16$ & 1.63 \\
\hline $\operatorname{RGM}\left(\mathrm{pg} / \mathrm{m}^{3}\right)$ & $21 \pm 47$ & 5 & $31 \pm 46$ & 18 & $91 \pm 109$ & 46 & $57 \pm 59$ & 37 & $9 \pm 17$ & 3 & $17 \pm 22$ & 12 \\
\hline$\sigma_{s p}\left(\mathrm{Mm}^{-1}\right)$ & $2.4 \pm 2.9$ & 1.2 & $3.3 \pm 3.7$ & 1.9 & $2.1 \pm 2.3$ & 1.3 & $3.3 \pm 3.9$ & 1.8 & $2.6 \pm 3.1$ & 1.0 & $4.3 \pm 3.7$ & 3.4 \\
\hline
\end{tabular}

\section{INTEX-B (spring 2006) vs. spring 2005: results}

\subsection{Interannual changes in springtime $\mathrm{CO}$ : $\mathrm{MBO}$}

The interannual variability in $\mathrm{CO}$ observed at $\mathrm{MBO}$ from spring 2005 to spring 2006 inspired much of this analysis. Figure 2a illustrates the complete timeseries of monthly mean CO at MBO from January 2004 through December 2007. Figure $2 \mathrm{~b}$ shows monthly $\mathrm{CO}$ anomalies referenced to monthly mean CO for the entire 2004-2007 period. Strong seasonal cycles are seen each year, illustrating a latewinter/early spring maximum (due to diminished $\mathrm{OH}$ concentrations from minimal sunlight throughout the winter) and a late summer minimum (when the $\mathrm{OH}$ sink is much stronger due to enhanced photochemical activity) common to continental background sites. Observed springtime (maximum) CO decreased by $41 \mathrm{ppbv}$ (21\%) from 2005 to 2006 . The large magnitude of the $\mathrm{CO}$ anomaly at $\mathrm{MBO}$ in early spring 2005 is illustrated in Fig. 2b.

\subsection{Interannual changes in springtime CO: GEOS-Chem chemical transport model}

To understand what drove this significant change in $\mathrm{CO}$ we compared measurements from MBO to total and Asiantagged CO using GEOS-Chem model sigma-levels 5-7. Figure 3 illustrates the percentage change in monthly $\mathrm{CO}$ from 2005 to 2006 using observations at MBO, GEOS-Chem model results and satellite retrievals over the NE Pacific. For March and April, the MBO observations, satellite measurements and GEOS-Chem Asian CO all showed significant declines from 2005 to 2006. GEOS-Chem showed a decline in total and Asian-tagged CO from spring 2005 to spring 2006. The magnitude of the percentage change is greater in the Asian-tagged $\mathrm{CO}(-4 \%$ to $-7 \%)$ than in total $\mathrm{CO}(+7 \%$ to $-6 \%$ ), indicating that the simulated decline is at least in part driven by changes in trans-Pacific transport of Asian CO. Results from the individual upper sigma-levels (6 and 7) show an even greater CO decrease (5-9\%). The GEOS-Chem results using climatological emissions do not fully capture the observed changes in $\mathrm{CO}$, arguing that some change in emissions probably occurred as well. This will be discussed in more detail in Sect. 7.

4.3 Interannual changes in springtime CO: MOPITT and TES satellite retrievals

Figure 3 also illustrates results from MOPITT and TES satellite retrievals from a box representative of the region around MBO, but placed just off-shore over the Northeast Pacific Ocean (for reasons detailed in Sect. 2.3). As Edwards et al. (2006) note, we should not expect CO mixing ratios from MOPITT mid-tropospheric retrievals (or those from TES) and measurements from a single point in space (e.g., MBO) to be quantitatively comparable as they sample different parts of the troposphere. Furthermore, MBO is in a region of complex terrain (Cascade Range), so in an effort to minimize the issues of topography while retaining some geographic representation, we used the over-ocean box for our retrievals and report the $\mathrm{CO}$ changes in Fig. 3 as percentages rather than mixing ratios. In Fig. 3 we show both the total column and $700 \mathrm{hPa}$ monthly changes in MOPITT CO between 2005 and 2006. The results from both pieces of information are quite similar, showing declines from April 2005 to April 2006 of $\sim 5 \%$. Mid-tropospheric $(562 \mathrm{hPa}) \mathrm{CO}$ from TES, on other hand, showed the greatest year-to-year decline $(\sim 7 \%)$ in March. Unlike MBO and GEOS-Chem, however, both satellite instruments detected an increase in $\mathrm{CO}$ from May 2005 to May 2006 of $\sim 7 \%$. While these changes may be close to the uncertainty in $\mathrm{CO}$ measurements from MOPITT and TES, the corroboration from other measurements and GEOS-Chem suggests they are real changes.

Taken together, we see fairly similar changes observed in springtime CO from MBO, GEOS-Chem and both MOPITT and TES satellite retrievals. The $\mathrm{CO}$ declines are greatest for April at MBO. The smaller changes seen in the GEOS-Chem simulations are largely caused by the utilization of constant, climatological emissions thereby reflecting changes in transport only. The observed decrease in April CO from 2005 to 2006 in MOPITT and TES is also less than that observed 
at MBO. This is most likely due to sampling differences: whereas observations at MBO are at one point in space, satellite data is representative of a larger region, both horizontally and vertically.

\subsection{Interannual changes in other species at $\mathrm{MBO}$}

Figure 4a-e show 3-day averages (datapoints represent the end-date of the 3-day mean) of various species $\left(\mathrm{CO}, \sigma_{s p}\right.$, $\mathrm{RGM}, \mathrm{O}_{3}$ and water vapor) measured at $\mathrm{MBO}$ throughout spring 2005 and 2006. Using 3-day averages allows us to smooth out most spikes due to transport events while still allowing a visualization of synoptic-scale resolution. Analysis of these plots allows us to paint a more complete picture of the differences between spring 2005 and spring 2006 at MBO. Figure 4a illustrates 3-day mean CO from 1 March-31 May of both years. Unfortunately, due to instrumental maintenance, a less-complete timeseries is available for 2006; however, significant differences between the two springs can readily be seen. CO is substantially greater in April 2005 than in April 2006. Three-day average CO mixing ratios upward of $180 \mathrm{ppbv}$ were observed, with episodes in excess of $200 \mathrm{ppbv}$. Towards the end of April and into May 2005, however, $\mathrm{CO}$ concentrations decreased to more climatological levels $(\sim 150 \mathrm{ppbv})$. In contrast, during April and May 2006 (i.e., INTEX-B) we observed CO levels of $\sim 140$ ppbv.

Figure $4 \mathrm{~b}$ shows the 3-day means of $\sigma_{s p}$ for the two years. Values in both spring seasons are fairly small in March, possibly due to the cloudier/stormier conditions leading to scavenging and wet deposition prior to sampling at MBO. The biggest difference between the two timeseries is seen in late April and May. Very large $\sigma_{s p}$ values were observed throughout late April and May 2006. The substantial variability seen in the 3-day average speaks to the episodic nature of strong aerosol events at MBO. These aerosol peaks also show minimal correlation to $\mathrm{CO}$, possibly indicating the role of a non-anthropogenic source. This observation is corroborated by two independent studies. Fischer et al. (2009) found spring 2006 to be an unusually strong season (when compared to 1998-2007) for Asian dust transport to the western US. They note that spring 2006 exhibited a large amount of dust mobilization over the Gobi and Taklimakan desert regions. The average aerosol optical depth (AOD) over this region was much higher than in 2005 and the Chinese Meteorological Association (CMA) reported the largest number of dust storms during this spring. The CMA record extends from 2000 to 2006. In addition, observations from the background Whistler mountaintop site in southwestern British Columbia, Canada ( $\sim 900 \mathrm{~km} \mathrm{NNW}$ of MBO) during INTEX-B showed several strong dust events in late April and May 2006 (McKendry et al., 2008). Furthermore, Fig. 5 shows vertical velocity $(\omega)$ from NCEP reanalysis (data provided by the NOAA/OAR/ESRL PSD, Boulder, Colorado, USA from their web site at http://www.cdc.noaa.gov). Figure $5 \mathrm{~b}$, d illustrate monthly mean $\omega$ for May 2005 and

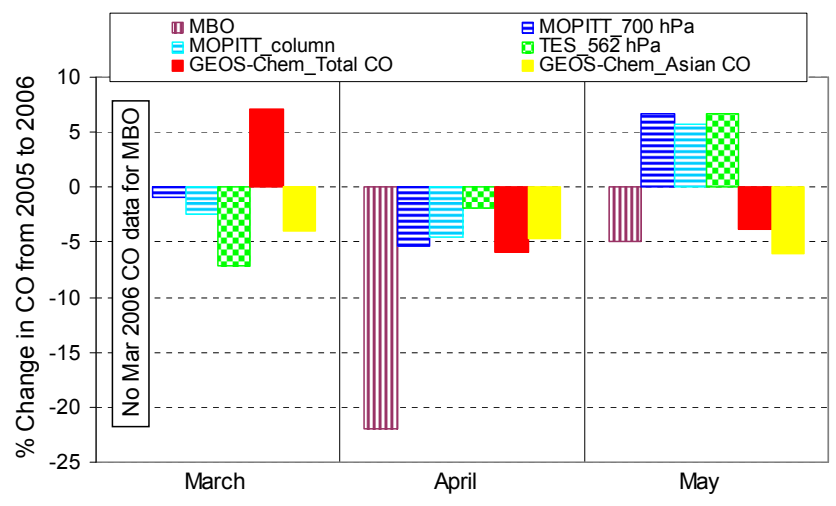

Fig. 3. Percent change in monthly CO from 2005 to 2006 from satellite retrievals near MBO, GEOS-Chem model results and $\mathrm{MBO}$ measurements (see Fig. 1 for spatially averaged regions). Note CO was not measured at MBO during March 2006.

2006 at $700 \mathrm{hPa}$, respectively. These images depict the more southerly location of the Pacific High in 2005 (between 30$\left.35^{\circ} \mathrm{N}\right)$ when compared to $2006\left(35-40^{\circ} \mathrm{N}\right)$. Together with the significantly smaller mean upward velocities over the northwestern US in May 2006, this pattern is consistent with a mean synoptic environment that was more conducive to large scale subsidence which is required to bring Asian LRT into the lower FT (Cooper et al., 2004).

Figure 4c-e depict 3-day averages of RGM, $\mathrm{O}_{3}$ and water vapor, respectively. Analyzing these three plots simultaneously provides insight into the relative degree of dry, FT, subsiding air being sampled at MBO. As Swartzendruber et al. (2006) note, significant enhancements in RGM are wellcorrelated with $\mathrm{O}_{3}$-rich air, both of which are representative of FT-influenced air. For most of May 2006 RGM and $\mathrm{O}_{3}$ were elevated, while water vapor was lower when compared to May 2005. While the RGM timeseries (Fig. 4c) is limited mostly to May of both years, we can see that in earlyto mid-May 2006 RGM enhancements were greater and of longer duration than for the same time in 2005. During this time, Fig. 4d shows enhancements in $\mathrm{O}_{3}$ upward of $60 \mathrm{ppbv}$ and Fig. 4e shows some of the driest air in either spring was sampled during this time in May 2006. These indicators support our findings, as well as those of Fischer et al. (2009) and McKendry et al. (2008), that May 2006 conditions in the northwest US/southwest Canada were particularly conducive to dry, subsiding air and an enhancement in dust transport originating in western Asia. 

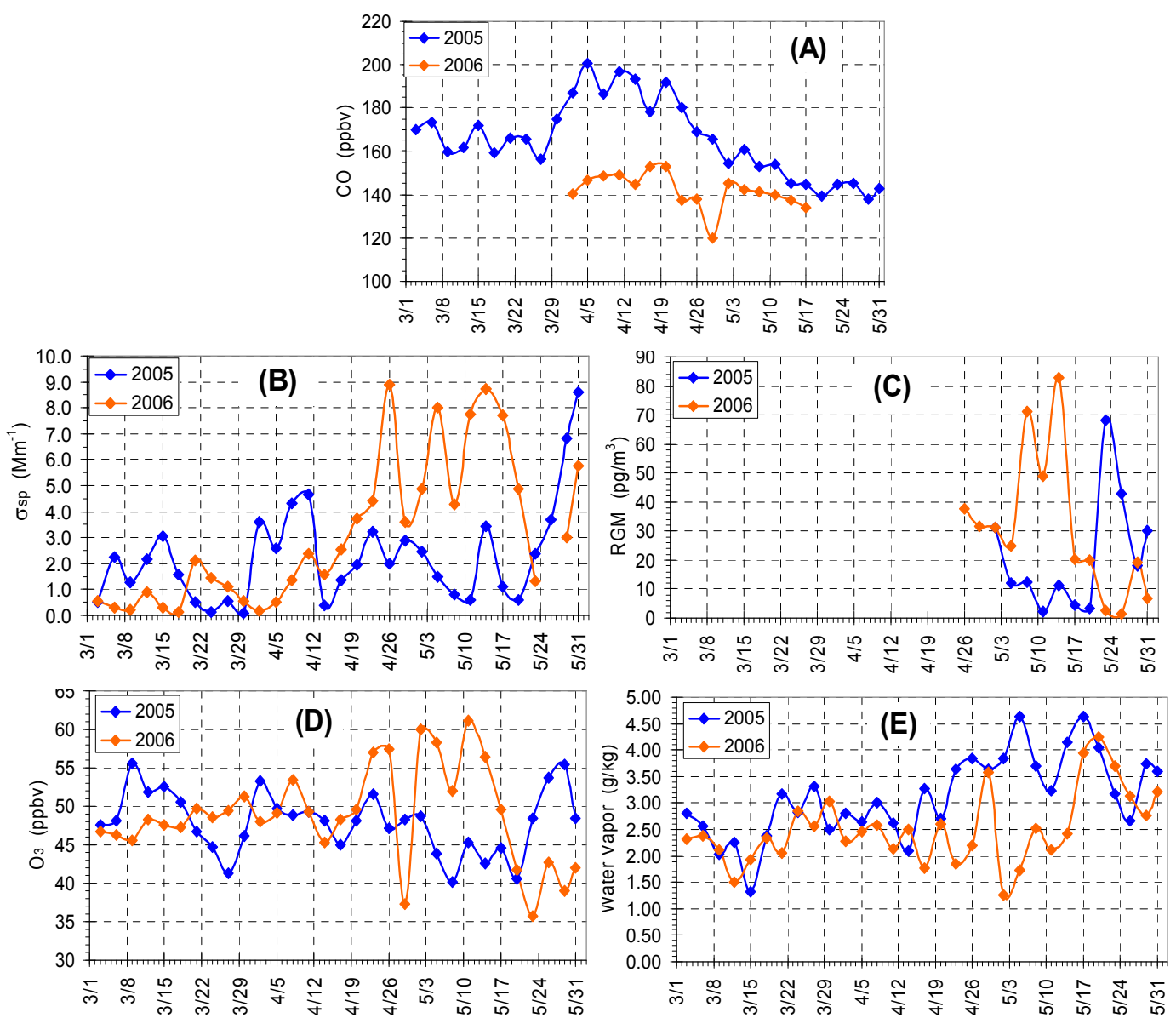

Fig. 4. 1 March-31 May 2005 vs. 2006 3-day averages of (A) CO, (B) $\sigma_{s p}$, (C) reactive gaseous $\mathrm{Hg}$, (D) $\mathrm{O}_{3}$ and (E) water vapor at MBO.

\section{INTEX-B (spring 2006) vs. spring 2005: analysis and implications}

\subsection{Backtrajectory analysis of Asian long-range transport to MBO}

To examine the role of trans-Pacific pollution transport, we compare our $\mathrm{CO}$ measurements with an ensemble backtrajectory analysis described in Sect. 2.4. Figures 6a and 7a display the average residence time in the East Asian box for backtrajectories initialized at MBO for 2005 and 2006, respectively. A timeseries from each spring is plotted as a function of backtrajectory initialization altitude. Such plots illustrate ALRT events at MBO when the colors appear in the region between (or below) the dotted lines. Such instances represent the transport mechanisms necessary to sample ALRT plumes at lower tropospheric sites. Whenever the color protrudes from the top of the plot, it implies that an airmass that has spent time in the BL of the predefined Asian box is subsiding. These plots are calculated from backtrajectories originating at $\mathrm{MBO}$, so any subsidence inferred from them is occurring near MBO or off the west coast of North America. Such a synoptic set-up is a springtime climatological feature described in more detail by Zhang et al. (2008). However, subsidence is not the sole transport mechanism responsible for bringing Asian emissions to the US FT and is not the only explanation for the patterns seen in Figs. 6 and 7. Emissions in the Asian BL can be lofted into the FT. These pollutants can then be horizontally advected across the Pacific and reach the FT along the west coast of North America. Pollutants at higher elevation will be transported more rapidly due to faster winds aloft. Subsidence may bring the pollutants to lower elevations over North America, but this depends on the specific meteorological situation. However, this does not change the result that the ALRT transport index is well-correlated with tracers emitted in the Asian BL. Figures 6 and 7, therefore, not only indicate periods of subsidence (when the color descends from the top of the plot), but also transport of emissions from the Asian BL via advection (when color appears between the dotted lines, but is not connected to color from aloft). 
Using Figs. 6a and 7a to compare predicted ALRT events with observations at MBO requires choosing HYSPLIT output from a representative altitude. The trajectory model calculates ground level for MBO to be 1.0$1.1 \mathrm{~km}$ a.s.l., whereas the actual observatory on the summit is at $2.76 \mathrm{~km}$ a.s.l. Thus, MBO is $\sim 1.7 \mathrm{~km}$ AGL for the FNL meteorological dataset. However, as Weiss-Penzias et al. (2006) discovered, it is often necessary to analyze backtrajectories at several initialization altitudes to adequately capture descending LRT plumes.

In Figs. $6 \mathrm{~b}$ and $7 \mathrm{~b}$, we plot the timeseries of the ALRT index (defined as the average number of hours the five backtrajectories initialized between 1.7 and $2.1 \mathrm{~km}$ AGL spent in the Asian box) for 2005 and 2006, respectively. Overlaid in red is the hourly timeseries of CO observations from MBO. Times when observed $\mathrm{CO}$ enhancements align with spikes in the ALRT index are highlighted with yellow boxes.

A direct correlation between $\mathrm{CO}$ concentrations and the ALRT index should not necessarily be expected as there are numerous other influences on the air sampled at MBO. In particular for $\mathrm{CO}$, biomass burning emissions from Indonesia, Siberia and Alaska have been observed at MBO and other ground sites in the northwestern US (Bertschi et al., 2004, 2005; Jaffe et al., 2004; Weiss-Penzias et al., 2007). Additionally, not all airmasses that have a long residence time in the Asian box will reach MBO with elevated CO levels as dilution and other chemical loss processes may deplete plume concentrations during transport. This is particularly true for shorter-lived species such as aerosols.

\subsection{Other indicators of Asian long-range transport to MBO}

Our conclusions regarding the interannual changes in transPacific transport are supported by other sources as well. The aerosol analyses of Fischer et al. (2009) and McKendry et al. (2008) suggest enhanced and significant transport of dust in late spring 2006, particularly in May. Swartzendruber et al. (2008) conducted 7 flights in a small aircraft over and just off the Washington State coast during INTEX-B. Outside of the Asian transport observed in late April, they found that plumes of Asian pollution remained at higher elevations (above $\sim 650 \mathrm{hPa}$ ) during the study period compared to other years. This is consistent with results from our backtrajectory analysis which suggests that there was, in general, weaker subsidence over the Northeast Pacific in the early spring of 2006 than during the same time in 2005.

As a more direct means of comparing subsidence of FT air in the broader eastern Pacific/western North America region for spring 2005 vs. spring 2006, we analyzed NCEP reanalysis vertical velocity $(\omega)$ in Fig. 5. Similar to Fig. 5b, d but for earlier in the spring, Fig. 5a, c illustrate mean $\omega$ for 1 March-30 April of 2005 and 2006 at $700 \mathrm{hPa}$, respectively. These plots illustrate that earlier in the spring upward motion over the west coast of the US was greater in 2006 than in 2005. Thus, it follows that the mean synoptic condition
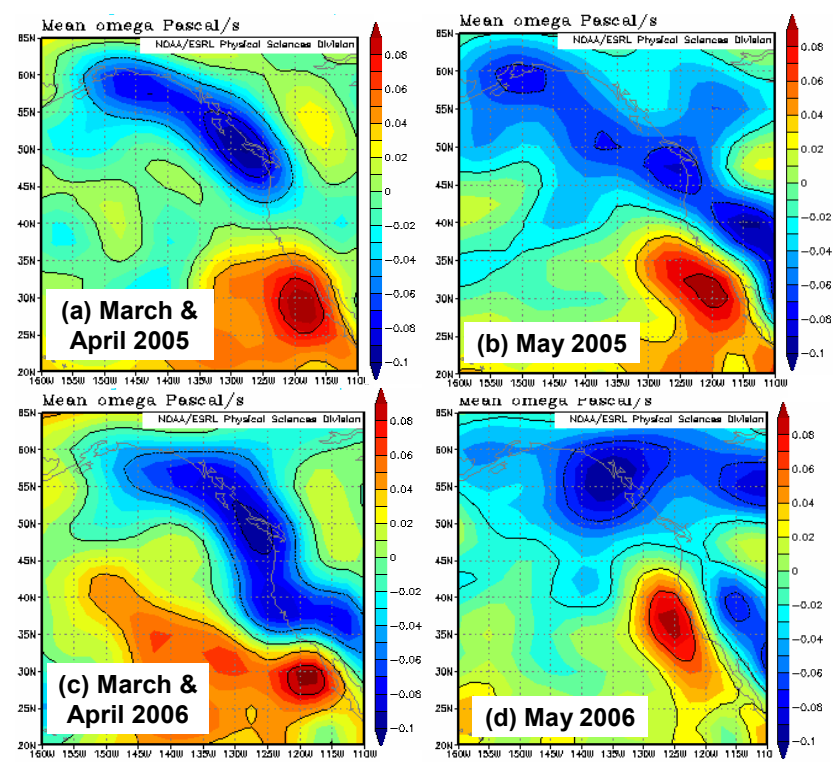

Fig. 5. NCEP reanalysis (from www.cdc.noaa.gov) of mean vertical velocity, $\omega$ (positive values indicate subsidence), at $700 \mathrm{hPa}$ over the eastern Pacific/western North America for (a) 1 March-30 April 2005, (b) May 2005, (c) 1 March-30 April 2006, (d) May 2006.

would be more conducive to subsidence of lower FT air in March and April of 2005 than for the same time in 2006.

Figures 6 and 7 illustrate the significant differences in ALRT influence in air sampled at MBO in spring 2005 vs. 2006. Multiple ALRT events are evident in March 2005 (Fig. 6a). In most instances, these ALRT episodes coincide with observed enhancements of $\mathrm{CO}$ and other pollutants at MBO. After mid-April 2005, however, there is a substantial decline in the ALRT influence. This is reflected in the $\mathrm{CO}$ measurements as well. In contrast, Fig. 7 shows far less ALRT influence throughout spring 2006, particularly in March. According to the backtrajectory index, the strongest event in either year occurred 23-24 April 2006 in the middle of INTEX-B. However, the enhancement in CO is only $\sim 25$ ppbv, far less than some of the other ALRT events. Examining Figs. 6 and 7 together illustrates the interannual differences in ALRT influence in air sampled at MBO. From 1 March through mid-April there is a far stronger influence of ALRT in 2005 than 2006, while late-April through mid-May shows slightly stronger ALRT influence in 2006 than 2005.

We have selected times when the ALRT index in Figs. $6 \mathrm{~b}$ and $7 \mathrm{~b}$ is greater than $20 \mathrm{~h}$ as being times when there is a potentially strong influence from the BL of the East Asian box. The largest $\mathrm{CO}$ enhancements tend to be observed when the ALRT index value is above $20 \mathrm{~h}$ (see highlighted boxes in Figs. $6 \mathrm{~b}$ and $7 \mathrm{~b}$ ). These times are compared to water vapor data collected at MBO. Both the ALRT index and the MBO water vapor measurements have $1 \mathrm{~h}$ resolution, so we compare the magnitude of the ALRT index to the water vapor values at the same time. Figure 8 shows times when the ALRT 


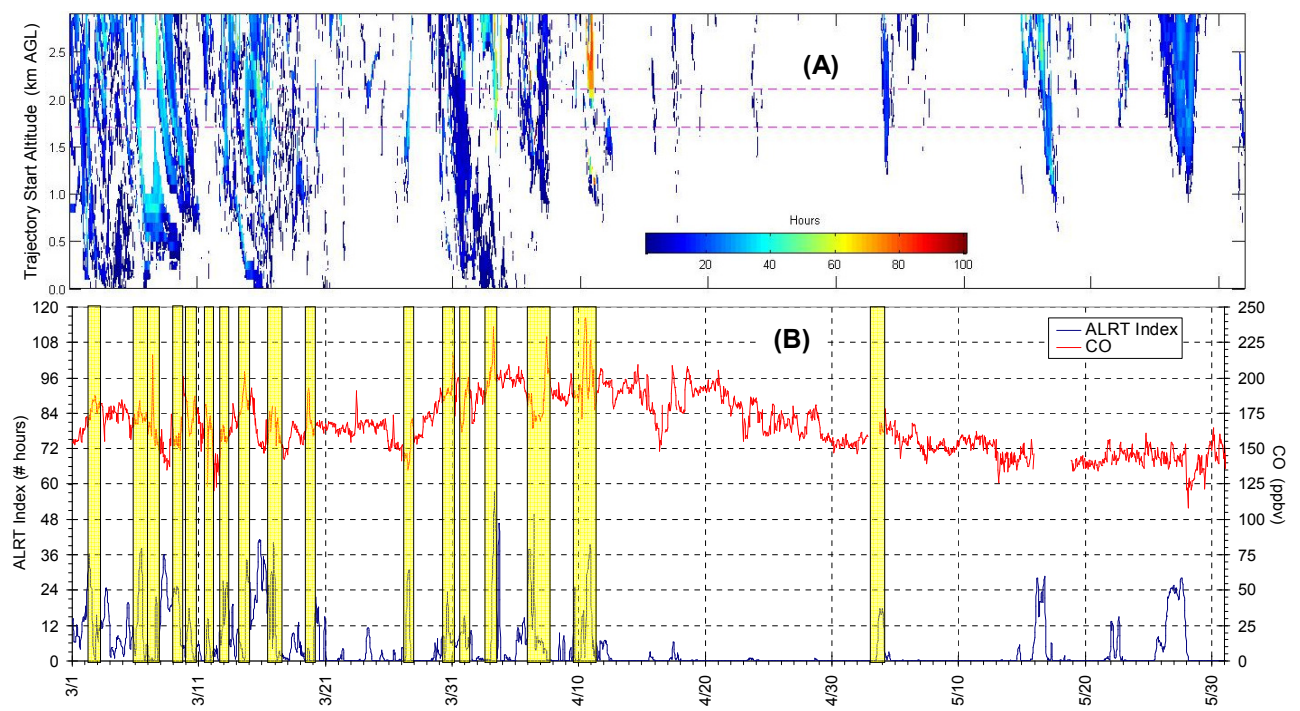

Fig. 6. (A) Average number of hours spent in the East Asian box for backtrajectories originating around MBO, as a function of backtrajectory start time and altitude for 2005. Results are plotted at $100 \mathrm{~m}$ intervals in the vertical for every hour between $1 \mathrm{March}-31 \mathrm{May}$. Regions in the plot that are white represent time/altitude pairs where no backtrajectories passed through the 0-3 km boundary layer of the East Asian box. The dashed magenta lines denote the range of data used to calculate the ALRT index (the approximate altitude of MBO, above model ground level [a.g.1.]). (B) Timeseries of ALRT Index and hourly CO at MBO for 1 March-31 May 2005. The ALRT Index is defined as the mean of the $1.7-2.1 \mathrm{~km}$ cross-sections of plot (A). Each point is the mean for 125 backtrajectories $(5 \times 5$ horizontal grid by 5 vertical levels). Yellow bars highlight events.

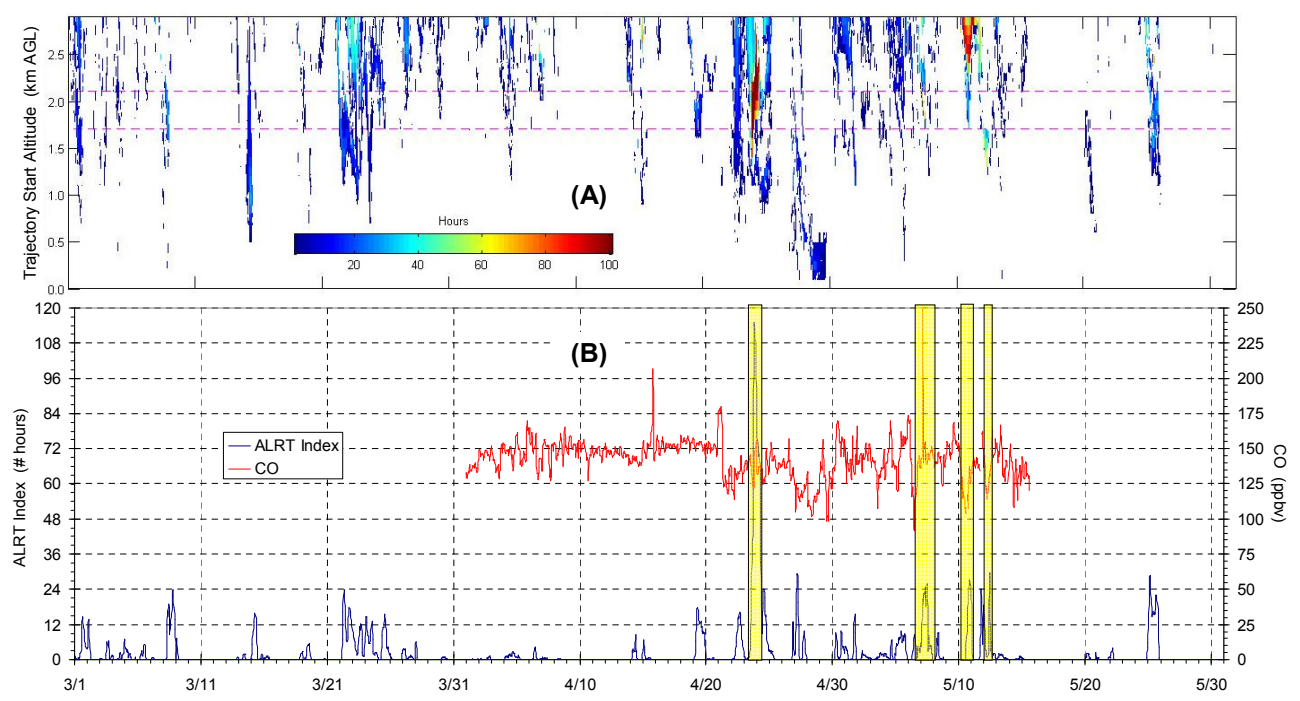

Fig. 7. Same as Fig. 6, but for 2006.

index $>20 \mathrm{~h}$ by 5 th, 20th and 33rd percentiles of water vapor data for spring 2005 and spring 2006. For example, in 2005 $20 \%$ of the hours when ALRT index was $>20 \mathrm{~h}$ occurred in the driest $5 \%$ of air whereas $18 \%$ of such hours occurred in the driest $5 \%$ of air in 2006. The differences in these values from 2005 to 2006 are to be expected since we have shown that the majority of ALRT in 2005 occurred in March (climatologically drier air), whereas the presence of ALRT in 2006 did not reach $\mathrm{MBO}$ until much later in the spring (when wetter air is being sampled more often at MBO). Furthermore, the results show that segregating MBO data by the driest $1 / 3$ is indeed a good first indicator of FT (and therefore potentially ALRT-influenced) air. This is certainly not to say that ALRT pollution cannot be seen in air with greater water vapor or RH, but rather that the enhancements due to ALRT are more probable in dry air. In fact, Wolfe et al. (2007) 


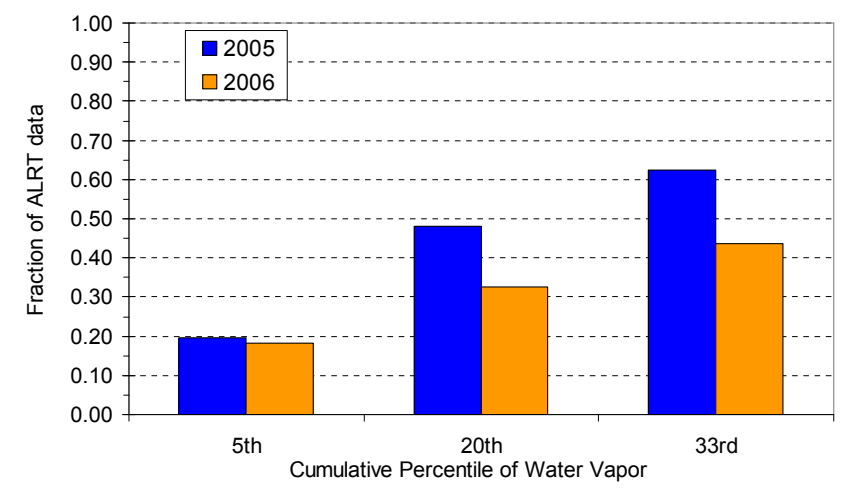

Fig. 8. The fraction of hourly springtime data with an ALRT Index $>20 \mathrm{~h}$ (see Figs. 6 and 7) for specified cumulative percentiles of water vapor data. For example, in 2005, the driest $5 \%$ of the hourly values contain $20 \%$ of the ALRT $>20 \mathrm{~h}$ times, the driest $20 \%$ of the hourly values contain $49 \%$ of the ALRT $>20 \mathrm{~h}$ times, etc.

separated their data into three distinct sets - "ALRT", "no ALRT" and "all" - and found that median water vapor as observed at MBO varied minimally between the three datasets, indicating that ALRT is not necessarily restricted to dry FT airmasses.

\section{Interannual variability of $\mathrm{CO}$ in the western US and Northern Hemisphere}

Figure 9 shows that significant changes in $\mathrm{CO}$ between spring 2005 and spring 2006 were observed throughout the western US Data from the Niwot Ridge, $\mathrm{CO}\left(40.05^{\circ} \mathrm{N}, 105.58^{\circ} \mathrm{W}\right.$; $3523 \mathrm{~m}$ a.s.1.) and Wendover, UT $\left(39.9^{\circ} \mathrm{N}, 113.72^{\circ} \mathrm{W}\right.$; $1320 \mathrm{~m}$ a.s.l.) ESRL sites that are relatively uninfluenced by local pollution both show a decline in the springtime maximum CO from 2005 to 2006. The lone ESRL high-altitude site, Niwot Ridge, showed changes in CO concentrations of similar magnitude to those observed at MBO (1 March-31 May mean decline of 13 ppbv at Niwot Ridge vs. 24 ppbv at $\mathrm{MBO}$ ), indicative of stronger $\mathrm{CO}$ enhancements in the lower FT for 2005 compared to 2006. It is quite possible that the magnitude of change in $\mathrm{CO}$ was not as great at the ESRL sites as it was at MBO due to temporal sampling issues. While MBO collects continuous hourly measurements, the ESRL network collects instantaneous flask samples about $4-5$ times per month.

Mid-tropospheric monthly mean TES and MOPITT CO retrievals averaged over the entire Northern Hemisphere $(\mathrm{NH})$ are also shown in Fig. 9. Similar patterns of decline in CO (though slightly smaller in magnitude) are seen over the entire hemisphere as was seen over the Northeast Pacific (Fig. 3). As might be expected, the changes are more nuanced when averaging spatially over the entire $\mathrm{NH}$ and accounting for the lower temporal resolution of satellite data, but there is still evidence of some large-scale changes.

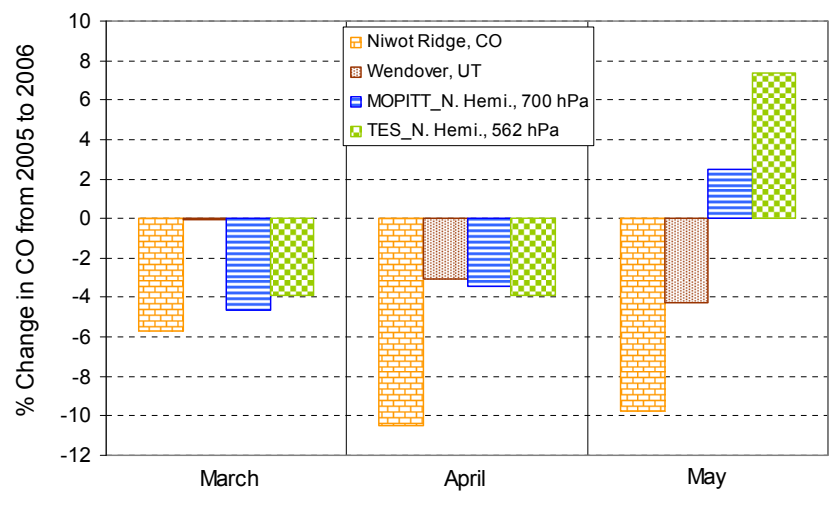

Fig. 9. Percent change in monthly mean CO from 2005 to 2006 beyond the Northeast Pacific region as measured via: ESRL measurements at Niwot Ridge, CO and Wendover, UT, as well as Northern Hemisphere mid-tropospheric MOPITT and TES satellite retrievals.

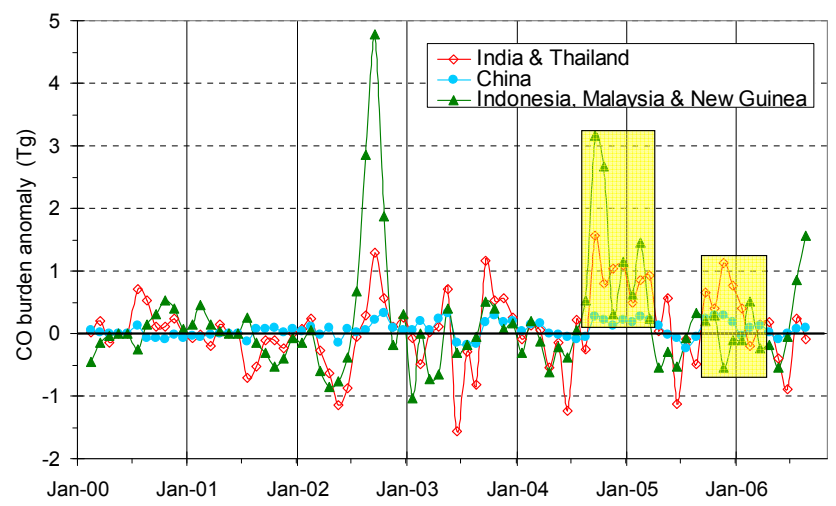

Fig. 10. Monthly mean $\mathrm{CO}$ burden anomalies (referenced to mean March 2000-February 2002 values) over selected regions: India and Thailand $\left(10^{\circ}-30^{\circ} \mathrm{N}, 70^{\circ}-110^{\circ} \mathrm{E}\right)$; Indonesia, Malaysia and New Guinea $\left(10^{\circ} \mathrm{S}-5^{\circ} \mathrm{N}, 95^{\circ}-145^{\circ} \mathrm{E}\right)$; and China $\left(25^{\circ}-40^{\circ} \mathrm{N}, 105^{\circ}\right.$ $120^{\circ} \mathrm{E}$ ), courtesy of L. Yurganov. Yellow boxes highlight relevant times for this study: anomalously high values in all regions from winter 2004 through spring 2005 vs. significantly lower CO burden anomalies from winter 2005 through spring 2006.

\section{Potential changes in $\mathrm{CO}$ emissions: the role of biomass burning}

The results presented in the previous section, coupled with findings from the GEOS-Chem simulations using constant, climatological emissions, indicate that variability in transport alone is not sufficient to explain the observed interannual variations in $\mathrm{CO}$. The episodic nature and large interannual variability of $\mathrm{CO}$ emissions from biomass burning appears to be the most likely non-meteorological cause.

There have been several studies into the impacts of wildfires on tropospheric composition for the period of interest in this study (van der Werf et al., 2006; Stohl et al., 2007; LePage et al., 2008; Tansey et al., 2008). Tansey et al. (2008) develop and validate a $1 \mathrm{~km}^{2}$ burnt area product for 


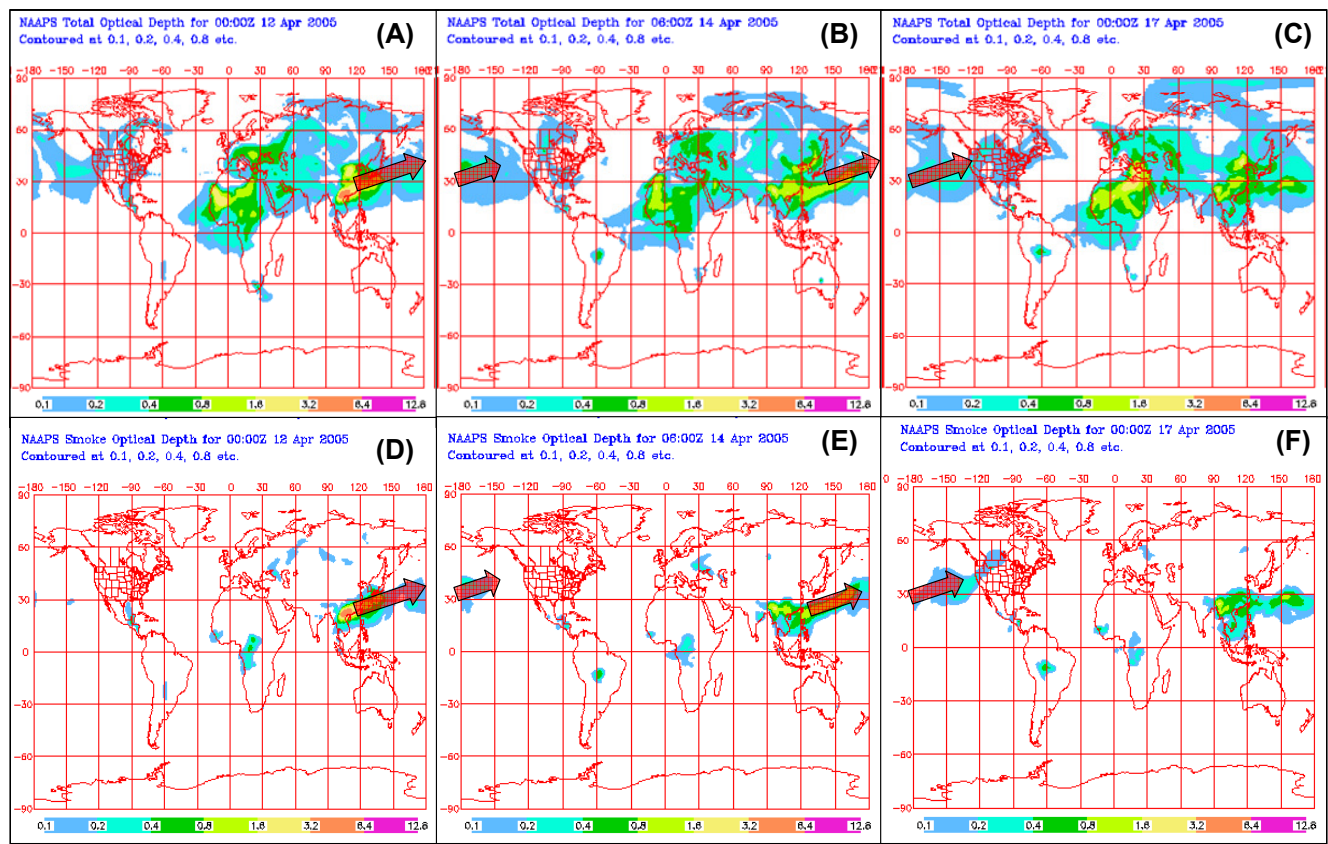

Fig. 11. Results from the Naval Research Laboratory's global aerosol transport model indicating transport of biomass burning emissions from Southeast Asia to the Northeast Pacific during April 2005. Figure 11a-c shows a timeseries of total aerosol optical depth (AOD) from 00:00 UTC on 12 April 2005 through 00:00 UTC on 17 April 2005. Figure 11d-f shows the same timeseries but for AOD attributable to smoke aerosols. The red arrows highlight transport of the biomass burning emissions to the Northeast Pacific via strong southwesterly flow; note transport time is only about 5 days.

2000-2007 using SPOT4 VEGETATION reflectance data. The authors found a steady decline in global burnt area from early 2002 through early 2006. Also relevant are the results from Yurganov et al. (2008). Using total column CO retrievals from MOPITT, the authors estimate CO burden anomalies referenced to mean March 2000-February 2002 values over selected regions. The reader is referred to Yurganov et al. (2008) for a more detailed description of the methodology employed to calculate these regional $\mathrm{CO}$ burden anomalies. Figure 10 illustrates MOPITT-derived CO burden anomalies (courtesy of L. Yurganov, 2008) for three regions of interest to this study: (1) India and Thailand $\left(10^{\circ}-30^{\circ} \mathrm{N}, 70^{\circ}-110^{\circ} \mathrm{E}\right)$, (2) Indonesia, Malaysia and New Guinea $\left(10^{\circ} \mathrm{S}-5^{\circ} \mathrm{N}, 95^{\circ}-145^{\circ} \mathrm{E}\right)$, and (3) China (25 $\left.40^{\circ} \mathrm{N}, 105^{\circ}-120^{\circ} \mathrm{E}\right)$. The significantly greater magnitude and variability in $\mathrm{CO}$ burden anomalies in the non-China regions signify the large interannual variations due to biomass burning in those regions. Conversely, the total column $\mathrm{CO}$ burden anomaly over China is much less variable year-toyear as it is dominated by consistent anthropogenic emissions. The $\mathrm{CO}$ burden anomalies over the India and Thailand and Indonesia, Malaysia and New Guinea regions are large and positive from winter 2004 through spring 2005, indicating intense biomass burning. The winter 2004-2005 burden anomaly is important in terms of pollution transport because $\mathrm{CO}$ emitted during winter tends to be longer-lived due to decreased OH mixing ratios (Holloway et al., 2000).
Corroborating this finding are results from the Naval Research Laboratory's global aerosol model (NAAPS, http://www.nrlmry.navy.mil/aerosol_web/Docs/ globaer_model.html), as presented in Fig. 11. Figure 11a-c illustrates an example of the influence emissions from fires in Southeast Asia had in the Northeast Pacific. Figure 11 shows a timeseries of modeled total aerosol optical depth (AOD) and depicts transport of biomass burning emissions originating in Southeast Asia to the Northeast Pacific from 00:00 UTC on 12 April-00:00 UTC on 17 April 2005. Figure 11d-f represents the same timeseries but for AOD attributable to smoke aerosols. The red arrows highlight the transport pathway to the Northeast Pacific via strong southwesterly flow. The transport time from source to receptor is only about 5 days, significantly shorter than typical trans-Pacific transport times (Akimoto et al., 1996; Jaffe et al., 1999, 2003; Liang et al., 2004). According to the NAAPS model, such transport pathways are common throughout April 2005. Intense biomass burning in Southeast Asia can lead to high smoke injection heights associated with convectively lofted plumes (Kahn et al., 2007, 2008). These plumes can then be transported rapidly via strong winds in the mid- to upper-troposphere which ultimately tend to subside over the western US.

Further evidence of transport of Southeast Asian wildfire emissions to the Northeast Pacific can be seen in NCEP reanalysis of FT winds from late March to early April 2005 
as shown in Fig. 12a. Figure $4 \mathrm{a}$ indicates that the $\mathrm{CO}$ enhancement observed at MBO occurred mostly from 29 March-5 April 2005 (and remained elevated through most of April). While the NAAPS aerosol transport model shows the Southeast Asian wildfire plume crossing the Pacific into midApril, these wind fields from the NCEP reanalysis show that a Southeast Asia-to-Northeast Pacific transport pathway had established itself a few weeks earlier. Given the prolonged enhancement of CO at MBO (late March through mid-April), both the NAAPS model results and the NCEP reanalysis wind fields support our source attribution. In Fig. 12, we highlight in red the "India and Thailand" box as described by Yurganov et al. (2008) in their analysis of regional CO burden anomalies. It is clear that wildfire emissions from this region that would be injected to altitudes in the lowerand middle-troposphere (i.e., 700 and $500 \mathrm{hPa}$ ) would then be efficiently transported to the west coast of North America due in large part to the shift from purely zonal winds to winds having a strong southwesterly component between $150-170^{\circ}$ E. Figure $12 \mathrm{~b}$ shows that this feature is a climatological anomaly, so the anomalous wildfire emissions from SE Asia, coupled with the anomalous transport pattern led to the observed $\mathrm{CO}$ enhancement. These results are the most convincing evidence that interannual wildfire variability, particularly the unusually strong fires in Southeast Asia during winter 2004 and spring 2005 drove the regional and NH interannual changes in $\mathrm{CO}$ presented here.

\section{Conclusions and summary}

We observe significant interannual variability in trans-Pacific transport of Asian pollution to western North America between spring 2005 and spring 2006. Ground-based measurements from MBO coupled with GEOS-Chem simulations suggest a significant change in ALRT between the two years. A comprehensive backtrajectory analysis confirms this, particularly for March and April. Results from aircraft measurements during the INTEX-B campaign (Swartzendruber et al., 2008) and the GEOS-Chem model (Zhang et al., 2008) show that the decline in CO from 2005 to 2006 was due, at least in part, to a smaller frequency of Asian LRT events reaching into the lower free troposphere over the Northeast Pacific during early spring 2006. In contrast, elevated levels of $\mathrm{O}_{3}, \mathrm{RGM}$ and $\sigma_{s p}$ in May 2006 vs. May 2005, along with the more southerly location of the Pacific High in 2005 when compared to 2006, indicate more long-range transport of aerosols (i.e., Asian dust as Fischer et al. (2009) show) during May 2006.

Results from ground site measurements and satellite observations beyond the Northeast Pacific also illustrate declines in lower- to mid-tropospheric CO levels from 2005 to 2006 (though smaller in magnitude than the changes observed at MBO). Regional total column CO burden anomalies from MOPITT satellite retrievals (Yurganov et al., 2008),
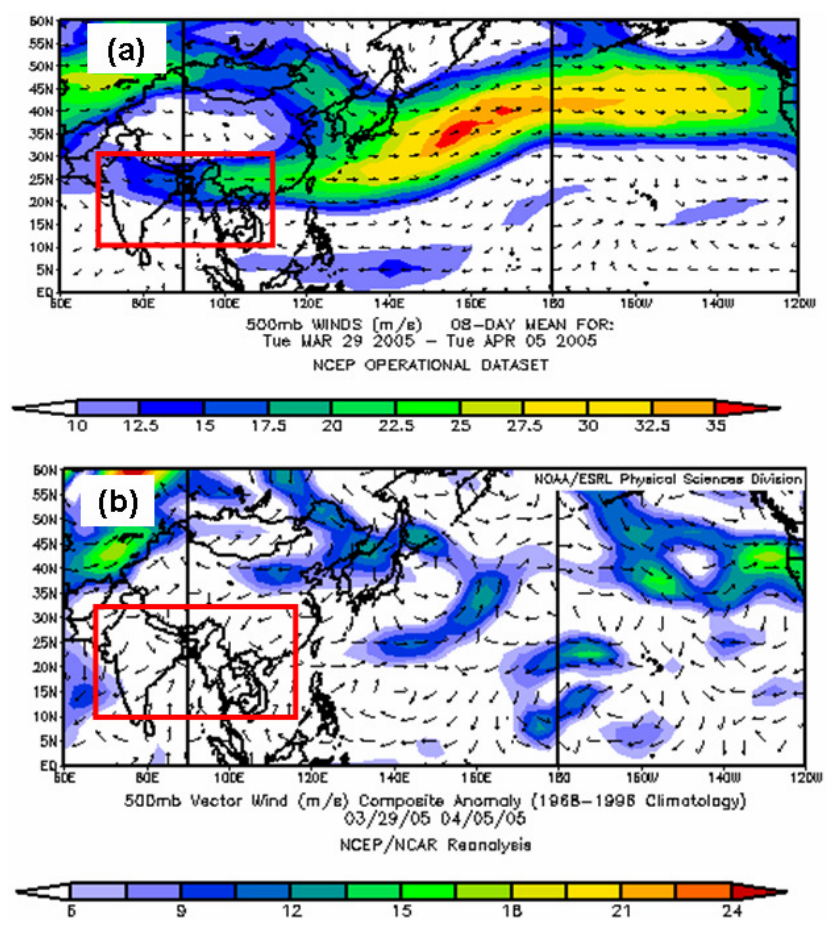

Fig. 12. NCEP reanalysis (from www.cdc.noaa.gov) of (a) winds at $500 \mathrm{hPa}$ from 29 March-5 April 2005 over the Pacific Ocean. The red box bounds the "India and Thailand" region $\left(10^{\circ}-30^{\circ} \mathrm{N}\right.$, $70^{\circ}-110^{\circ} \mathrm{E}$ ) used by Yurganov et al. (2008) to show that wildfire emissions in early spring 2005 caused anomalously large CO burden anomalies. Note the shift from purely zonal winds to those with a strong southwesterly component between $150-170^{\circ} \mathrm{E}$, allowing emissions from Southeast Asia to be efficiently transported to the west coast of North America. Frame (b) shows the climatological anomaly of this feature when compared to 1968-1996.

transport pathways elucidated from the NAAPS global aerosol transport model and winds from NCEP reanalysis confirm that unusually strong fires in Southeast Asia played a large role in enhancing $\mathrm{CO}$ over the Northeast Pacific and western US in spring 2005, particularly from late March into mid-April. Taken together, the results presented suggest that a combination of: (1) fewer ALRT events reaching into the lower FT over the northeast Pacific in early spring 2006, (2) anomalously strong wildfires in Southeast Asia during early spring 2005 coupled with a transport pathway that allowed for rapid trans-Pacific transport to the west coast of the US, and (3) a slightly different synoptic pattern over western North America that was more conducive to downward mixing in 2005, drove the observed interannual changes in CO. We have shown that there can be a high degree of interannual variability in CO. This highlights the scientific importance of continuous monitoring of both species since selective temporal sampling will not provide a true picture of annual and interannual atmospheric variability. 
Acknowledgements. This work has been funded in large part by NSF grant ATM-0724327. The authors also wish to thank Louisa Emmons (NCAR) for providing the MOPITT data; Greg Osterman and Ming Luo (NASA-JPL) for providing the TES data; Paul Novelli (NOAA-ESRL) for providing the ESRL CO data; and Leonid Yurganov (University of Maryland - Baltimore County) for providing the regional total column $\mathrm{CO}$ burden anomalies from MOPITT. G. Wolfe acknowledges support from NASA Earth Systems Science Fellowship NNG-05GP64H.

Edited by: H. Singh

\section{References}

Akimoto, H., Mukai, H., Nishikawa, M., Murano, K., Hatakeyama, S., Liu, C.-M., Buhr, M., Hsu, K. J., Jaffe, D. A., Zhang, L., Honrath, R., Merrill J. T., and Newell, R. E.: Long-range transport of ozone in the East Asian Pacific rim region, J. Geophys. Res., 101(D1), 1999-2010, 1996.

Akimoto, H.: Global Air Quality and Pollution, Science, 302, 1716-1719, 2003.

Allen, D. J., Kasibhatla, P., Thompson, A. M., Rood, R. B., Doddridge, B. G., Pickering, K. E., Hudson, R. D., and Lin, S.J.: Transport-induced interannual variability of carbon monoxide determined using a chemistry and transport model, J. Geophys. Res., 101(D22), 28655-28669, 1996.

Auvray, M., Bey, I., Llull, E., Schultz, M. G., and Rast, S.: A model investigation of tropospheric ozone tendencies in long-range transported pollution plumes, J. Geophys. Res., 112, D05304, doi:10.1029/2006JD007137, 2007.

Beer, R., Glavich, T. A., and Rider, D. M.: Tropospheric Emissions Spectrometer for the Earth Observing System Aura satellite, Appl. Optics, 40, 2356-2367, 2001.

Bertschi, I. B., Jaffe, D. A., Jaeglé, L., Price, H. U., and Dennison, J. B.: PHOBEA/ITCT 2002 airborne observations of trans-Pacific transport of ozone, $\mathrm{CO}$, VOCs and aerosols to the northeast Pacific: Impacts of Asian anthropogenic and Siberian Boreal fire emissions, J. Geophys. Res., 109, D23S12, doi:10.1029/2003JD004328, 2004.

Bertschi, I. B. and Jaffe, D. A.: Long-Range transport of ozone, carbon monoxide and aerosols to the NE Pacific Troposphere during the summer of 2003: Observations of smoke plumes from Asian Boreal fires, J. Geophys. Res., 110, D05303, doi:10.1029/2004JD005135, 2005.

Bey, I., Jacob, D. J., Yantosca, R. M., Logan, J. A., Field, B. D., Fiore, A. M., Li, Q., Liu, H., Mickley, L. J., and Schultz, M. G.: Global modeling of tropospheric chemistry with assimilated meteorology: Model description and evaluation, J. Geophys. Res., 106(D19), 23073-23095, 2001.

Brasseur, G. P., Hauglustaine, D. A., Walters, S., Rasch, P. J., Muller, J.-F., Granier, C., and Tie, X. X.: MOZART: A global chemical transport model for ozone and related chemical tracers: Part 1, Model description, J. Geophys. Res., 103(D21), 2825628289, 1998.

Cooper, O. R., Forster, C., Parrish, D., Trainer, M., Dunlea, E., Ryerson, T., Hubler, G., Fehsenfeld, F., Nicks, D., Holloway, J., de Gouw, J., Warneke, C., Roberts, J. M., Flocke, F., and Moody, J.: A case study of transpacific warm conveyor belt transport: Influence of merging airstreams on trace gas import to North America,
J. Geophys. Res., 109, D23S08, doi:10.1029/2003JD003624, 2004.

Deeter, M. N., Emmons, J., Francis, G. L., Edwards, D. P., Gille, J. C., Warner, J. X., Khattatov, B., Ziskin, D., Lamarque, J.-F., Ho, S.-P., Yudin, V., Attié, J.-L., Packman, D., Chen, J., Mao, D., and Drummond, J. R.: Operational carbon monoxide retrieval algorithm and selected results from the MOPITT instrument, J. Geophys. Res., 108(D14), 4399, doi:10.1029/2002JD003186, 2003.

Deeter, M. N., Edwards, D. P., Gille, J. C., and Drummond, J. R.: Sensitivity of MOPITT observations to carbon monoxide in the lower troposphere, J. Geophys. Res., 112, D24306, doi:10.1029/2007JD008929, 2007.

Draxler, R. R. and Rolph, G. D.: HYSPLIT (HYbrid SingleParticle Lagrangian Integrated Trajectory) Model access via NOAA ARL READY web site, NOAA Air Resources Laboratory, Silver Spring, MD, available at: http://www.arl.noaa.gov/ ready/hysplit4.html, last accessed May 2008.

Drummond, J. R. and Mand, G. S.: The Measurement of Pollution in the Troposphere (MOPITT) instrument: Overall performance and calibration requirements, J. Atmos. Ocean. Tech., 13, 314320, 1996.

Duncan, B. N., Martin, R. V., Staudt, A. C., Yevich, R., and Logan, J. A.: Interannual and seasonal variability of biomass burning emissions constrained by satellite observations, J. Geophys. Res., 108(D2), 4100, doi:10.1029/2002JD002378, 2003.

Edwards, D. P., Pétron, G., Novelli, P. C., Emmons, L. K., Gille, J. C., and Drummond, J. P.: Southern Hemisphere carbon monoxide interannual variability observed by Terra/Measurement of Pollution in the Troposphere (MOPITT), J. Geophys. Res., 111, D16303, doi:10.1029/2006JD007079, 2006.

Emmons, L. K., Deeter, M. N., Gille, J. C., Edwards, D. P., Attíe, J.-L., Warner, J., Ziskin, D., Francis, G., Khattatov, B., Yudin, V., Lamarque, J.-F., Ho, S.-P., Mao, D., Chen, J. S., Drummond, J., Novelli, P., Sasche, G., Coffey, M. T., Hannigan, J. W., Gerbig, C., Kawakami, S., Kondo, Y., Takegawa, N., Schlager, H., Baehr, J., and Ziereis, H.: Validation of Measurements of Pollution in the Troposphere (MOPITT) CO retrievals with aircraft in situ profiles, J. Geophys. Res., 109, D03309, doi:10.1029/2003JD004101, 2004.

Emmons, L. K., Pfister, G. G., Edwards, D. P., Gille, J. C., Sachse, G., Blake, D., Wofsy, S., Gerbig, C., Matross, D., and Nédélec, P.: Measurements of Pollution in the Troposphere (MOPITT) validation exercises during summer 2004 field campaigns over North America, J. Geophys. Res., 112, D12S02, doi:10.1029/2006JD007833, 2007.

Fischer, E. V., Hsu, N. C., Jaffe, D. A., Jeong, M.-J., and Gong, S. L.: A decade of dust: Asian dust and springtime aerosol load in the U.S. Pacific northwest, Geophys. Res. Lett., doi:10.1029/2008GL036467, in press, 2009.

Goldstein, A. H., Millet, D. B., McKay, M., Jaeglé, L., Horowitz, L., Cooper, O., Hudman, R., Jacob, D. J., Oltmans, S., and Clarke, A.: Impact of Asian emissions on observations at Trinidad Head, California during ITCT 2K2, J. Geophys. Res., 109, D23S17, doi:10.1029/2003JD004406, 2004.

Granier, C., Müller, J.-F., Madronich, S., and Brasseur, G. P.: Possible causes for the 1990-1993 decrease in the global tropospheric CO abundances: A three-dimensional sensitivity study, Atmos. Environ., 30, 1673-1682, 1996.

Hafner, W. D., Solorzano, N. N., and Jaffe, D. A.: Analysis of 
rainfall and fine aerosol data using clustered trajectory analysis for National Park sites in the Western U.S., Atmos. Environ., 41, 3071-3081, 2007.

Hemispheric Transport of Air Pollution (HTAP): Interim Report, United Nations Press, New York City, 165 pp., 2007.

Holloway, T., Levy, H., and Kasibhatla, P.: Global distribution of carbon monoxide, J. Geophys. Res., 105(D10), 12123-12147, 2000.

Holzer, M. and Hall, T. M.: Low-level transpacific transport, J. Geophys. Res., 112, D09103, doi:10.1029/2006JD007828, 2007.

Irie, H., Sudo, K., Akimoto, H., Richter, A., Burrows, J. P., Wagner, T., Wenig, M., Beirle, S., Kondo, Y., Sinyakov, V. P., and Goutail, F.: Evaluation of long-term tropospheric $\mathrm{NO}_{2}$ data obtained by GOME over East Asia in 1996-2002, Geophys. Res. Lett., 32(11), L11810, doi:10.1029/2005GL022770, 2005.

Jaffe, D., Anderson, T., Covert, D., Kotchenruther, R., Trost, B., Danielson, J., Simpson, W., Berntsen, T., Karlsdottir, S., Blake, D., Harris, J., Carmichael, G., and Uno, I.: Transport of Asian air pollution to North America, Geophys. Res. Lett., 26(6), 711714, 1999.

Jaffe, D., Anderson, T., Covert, D., Trost, B., Danielson, J., Simpson, W., Blake, D., Harris, J., and Streets, D.: Observations of ozone and related species in the northeast Pacific during the PHOBEA campaigns: 1. Ground-based observations at Cheeka Peak, J. Geophys. Res., 106(D7), 7449-7461, 2001.

Jaffe D., McKendry, I., Anderson, T., and Price, H.: Six "new" episodes of trans-Pacific transport of air pollutants, Atmos. Environ., 37, 391-404, 2003.

Jaffe, D., Bertschi, I., Jaeglé, L., Novelli, P., Reid, J. S., Tanimoto, H., Vingarzan, R., and Westphal, D. L.: Long-range transport of Siberian biomass burning emissions and impact on surface ozone in western North America, Geophys. Res. Lett., 31, L16106, doi:10.1029/2004GL020093, 2004.

Jaffe, D., Prestbo, E., Swartzendruber, P., Weiss-Penzias, P., Kato, S., Takami, A., Hatakeyama, S., and Kajii, Y.: Export of atmospheric mercury from Asia, Atmos. Environ., 39, 3029-3038, 2005.

Jaffe, D. and Ray, J.: Increase in surface ozone at rural sites in the western U.S., Atmos. Environ., 41, 5452-5463, 2007.

Kahn, R. A., Li, W.-H., Moroney, C., Diner, D. J., Martonchik, J. V., and Fishbein, E.: Aerosol source plume physical characteristics from space-based multiangle imaging, J. Geophys. Res., 112, D11205, doi:10.1029/2006JD007647, 2007.

Kahn, R. A., Chen, Y., Nelson, D. L., Leung, F.-Y., Li, Q., Diner, D. J., and Logan, J. A.: Wildfire smoke injection heights: Two perspectives from space, Geophys. Res. Lett., 35, L04809, doi:10.1029/2007GL032165, 2008.

Khalil, M. A. K. and Rasmussen, R. A.: Carbon monoxide in the Earth's atmosphere: indications of a global increase, Nature, 332, 242-244, 1988.

Khalil, M. A. K. and Rasmussen, R. A.: Global decrease in atmospheric carbon monoxide concentration, Nature, 370, 639-641, 1994.

Kulawik, S. S., Worden, J., Eldering, A., Bowman, K., Gunson, M., Osterman, G. B., Zhang, L., Clough, S. A., Shephard, M. W., and Beer, R.: Implementation of cloud retrievals for Tropospheric Emissions Spectrometer (TES) atmospheric retrievals: 1. Description and characterization of errors on trace gas retrievals, J. Geophys. Res., 111, D24204, doi:10.1029/2005JD006733, 2006.
Le Page, Y., Pereira, J. M. C., Trigo, R., da Camara, C., Oom, D., and Mota, B.: Global fire activity patterns (1996-2006) and climatic influence: an analysis using the World Fire Atlas, Atmos. Chem. Phys., 8, 1911-1924, 2008,

http://www.atmos-chem-phys.net/8/1911/2008/.

Liang, Q., Jaeglé, L., Jaffe, D. A., Weiss-Penzias, P., Heckman, A., and Snow, J. A.: Long-range transport of Asian pollution to the northeast Pacific: Seasonal variations and transport pathways of carbon monoxide. J. Geophys. Res., 109, D23S07, doi:10.1029/2003JD004402, 2004.

Liang, Q., Jaeglé, L., and Wallace, J. M.: Meteorological indices for Asian outflow and transpacific transport on daily to interannual timescales, J. Geophys. Res., 110, D18308, doi:10.1029/2005JD005788, 2005.

Liang, Q., Jaeglé, L., Hudman, R. C., Turquety, S., Jacob, D. J., Avery, M. A., Browell, E. V., Sachse, G. W., Blake, D. R., Brune, W., Ren, X., Cohen, R. C., Dibb, J. E., Fried, A., Fuelberg, H., Porter, M., Heikes, B. G., Huey, G., Singh, H. B., and Wennberg, P. O.: Summertime influence of Asian pollution in the free troposphere over North America, J. Geophys. Res., 112, D12S11, doi:10.1029/2006JD007919, 2007.

Liu, H., Jacob, D. J., Bey, I., Yantosca, R. M., Duncan, B., and Sasche, G. W.: Transport pathways for Asian pollution outflow over the Pacific: Interannual and seasonal variations, J. Geophys. Res., 108(D20), 8786, doi:10.1029/2002JD003102, 2003.

Luo, M., Rinsland, C., Fisher, B., Sasche, G., Diskin, G., Logan, J., Worden, H., Kulawik, S., Osterman, G., Eldering, A., Herman, R., and Shephard, M.: TES carbon monoxide validation with DACOM aircraft measurements during INTEX-B 2006, J. Geophys. Res., 112, D24S48, doi:10.1029/2007JD008803, 2007a.

Luo, M., Rinsland, C. P., Rodgers, C. D., Logan, J. A., Worden, H., Kulawik, S., Eldering, A., Goldman, A., Shephard, M. W., Gunson, M., and Lampel, M.: Comparison of carbon monoxide measurements by TES and MOPITT: Influence of a priori data and instrument characteristics on nadir atmospheric species retrievals, J. Geophys. Res., 112, D09303, doi:10.1029/2006JD007663, 2007b.

McKendry, I. G., Macdonald, A. M., Leaitch, W. R., van Donkelaar, A., Zhang, Q., Duck, T., and Martin, R. V.: Trans-Pacific dust events observed at Whistler, British Columbia during INTEX-B, Atmos. Chem. Phys., 8, 6297-6307, 2008, http://www.atmos-chem-phys.net/8/6297/2008/.

Novelli, P. C., Masarie, K. A., and Lang, P. M.: Distributions and recent changes of carbon monoxide in the lower troposphere, J. Geophys. Res., 103(D15), 19015-19033, 1998.

Osterman, G., Bowman, K., Cady-Pereira, K., et al.: Tropospheric Emissions Spectrometer (TES) validation report, JPL D33192, version 1.0, Jet Propul. Lab., Pasadena, Calif, (available at: http: //tes.jpl.nasa.gov/documents/), 2005.

Parrish, D. D., Kondo, Y., Cooper, O. R., Brock, C. A., Jaffe, D. A., Trainer, M., Ogawa, T., Hübler, G., and Fehsenfeld, F. C.: Intercontinental Transport and Chemical Transformation 2002 (ITCT 2K2) and Pacific Exploration of Asian Continental Emission (PEACE) experiments: An overview of the 2002 winter and spring intensives, J. Geophys. Res., 109, D23S01, doi:10.10292004JD004980, 2004.

Richter, A., Burrows, J. P., Nüß, H., Granier, C., and Niemeier, U.: Increase in tropospheric nitrogen dioxide over China observed from space, Nature, 437, 129-132, 2005. 
Rinsland, C. P., Luo, M., Logan, J. A., Beer, R., Worden, H., Kulawik, S. S., Rider, D., Osterman, G., Gunson, M., Eldering, A., Goldman, A., Shephard, M., Clough, S. A., Rodgers, C., Lampel, M., and Chiou, L.: Nadir measurements of carbon monoxide distributions by the Tropospheric Emission Spectrometer instrument onboard the Aura Spacecraft: Overview of analysis approach and examples of initial results, Geophys. Res. Lett., 33, L22806, doi:10.1029/2006GL027000, 2006.

Singh, H. B., Brune, W. H., Crawford, J. H., Flocke, F., and Jacob, D. J.: Chemistry and transport of pollution over the Gulf of Mexico and the Pacific: Spring 2006 INTEX-B Campaign overview and first results, Atmos. Chem. Phys. Discuss., 9, 363-409, 2009, http://www.atmos-chem-phys-discuss.net/9/363/2009/.

Stohl, A., Eckhardt, S., Forster, C., James, P., Spichtinger, N., and Seibert, P.: A replacement for simple backtrajectory calculations in the interpretation of atmospheric trace gas substance measurements, Atmos. Environ., 36, 4635-4648, 2002.

Stohl, A., Berg, T., Burkhart, J. F., Fjǽraa, A. M., Forster, C., Herber, A., Hov, Ø., Lunder, C., McMillan, W. W., Oltmans, S., Shiobara, M., Simpson, D., Solberg, S., Stebel, K., Ström, J., Tørseth, K., Treffeisen, R., Virkkunen, K., and Yttri, K. E.: Arctic smoke - record high air pollution levels in the European Arctic due to agricultural fires in Eastern Europe in spring 2006, Atmos. Chem. Phys., 7, 511-534, 2007, http://www.atmos-chem-phys.net/7/511/2007/.

Swartzendruber, P. C., Jaffe, D. A., Prestbo, E. M., Weiss-Penzias, P., Selin, N. E., Park, R., Jacob, D. J., Strode, S., and Jaeglé, L.: Observations of reactive gaseous mercury in the free troposphere at the Mt. Bachelor Observatory, J. Geophys. Res., 111, D24301, doi:10.1029/2006JD007415, 2006.

Swartzendruber, P. C., Chand, D., Jaffe, D. A., Smith, J., Reidmiller, D., Gratz, L., Keeler, J., Strode, S., Jaeglé, L., and Talbot, R.: The vertical distribution of mercury, CO, ozone, and aerosol scattering coefficient in the Pacific Northwest during the spring 2006 INTEX-B campaign, J. Geophys. Res., 113, D10305, doi:10.1029/2007JD009579, 2008.

Szopa, S., Hauglustaine, D. A., and Ciais, P.: Relative contributions of biomass burning emissions and atmospheric transport to carbon monoxide interannual variability, Geophys. Res. Lett., 34, L18810, doi:10.1029/2007GL030231, 2007.

Tansey, K., Grégoire, J.-M., Defourny, P., Leigh, R., Pekel, J.-F., vanBogaert, E., and Bartholomé, E.: A new, global, multi-annual (2000-2007) burnt area product at $1 \mathrm{~km}$ resolution, Geophys. Res. Lett., 35, L01401, doi:10.1029/2007GL031567, 2008.

van der Werf, G. R., Randerson, J. T., Giglio, L., Collatz, G. J., Kasibhatla, P. S., and Arellano Jr., A. F.: Interannual variability in global biomass burning emissions from 1997 to 2004, Atmos. Chem. Phys., 6, 3423-3441, 2006,

http://www.atmos-chem-phys.net/6/3423/2006/.
Wang, Y., Shim, C., Blake, N., Blake, D., Choi, Y., Ridley, B., Dibb, J., Wimmers, A., Moody, J., Flocke, F., Weinheimer, A., Talbot, R., and Atlas, E.: Intercontinental transport of pollution manifested in the variability and seasonal trend of springtime $\mathrm{O}_{3}$ at northern middle and high latitudes, J. Geophys. Res., 108(D21), 4683, doi:10.1029/2003JD003592, 2003.

Wang, Y., Choi, Y., Zeng, T., Ridley, B., Blake, N., Blake, D., and Flocke, F.: Late-spring increase of trans-Pacific pollution transport in the upper troposphere, Geophys. Res. Lett., 33, L01811, doi:10.1029/2005GL024975, 2006.

Warner, J., McCourt-Comer, M., Barnet, C. D., McMillan, W. W., Wolf, W., Maddy, E., and Sasche, G.: A comparison of satellite tropospheric carbon monoxide measurements from AIRS and MOPITT during INTEX-A, J. Geophys. Res., 112, D12S17, doi:10.1029/2006JD007925, 2007.

Weiss-Penzias, P., Jaffe, D. A., Jaeglé, L., and Liang, Q.: Influence of long-range-transported pollution on the annual and diurnal cycles of carbon monoxide and ozone at Cheeka Peak Observatory, J. Geophys. Res., 109, D23S14, doi:10.1029/2004JD004505, 2004.

Weiss-Penzias, P., Jaffe, D. A., Swartzendruber, P., Dennison, Chand, D., Hafner, W., and Prestbo, E.: Observations of Asian air pollution in the free troposphere at Mt. Bachelor Observatory during the spring of 2004, J. Geophys. Res., 111, D10304, doi:10.1029/2005JD006522, 2006.

Weiss-Penzias, P., Jaffe, D., Swartzendruber, P., Hafner, W., Chand, D., and Prestbo, E.: Quantifying Asian and biomass burning sources of mercury using the $\mathrm{Hg} / \mathrm{CO}$ ratio in pollution plumes observed at the Mt. Bachelor Observatory, Atmos. Environ., 41, 4366-4379, 2007.

Wolfe, G. M., Thornton, J. A., McNeill, V. F., Jaffe, D. A., Reidmiller, D., Chand, D., Smith, J., Swartzendruber, P., Flocke, F., and Zheng, W.: Influence of trans-Pacific pollution transport on acyl peroxy nitrate abundances and speciation at Mount Bachelor Observatory during INTEX-B, Atmos. Chem. Phys., 7, 53095325, 2007, http://www.atmos-chem-phys.net/7/5309/2007/.

Yurganov, L. N., McMillan, W. W., Dzhola, A. V., Grechko, E. I., Jones, N. B., and van der Werf, G. R.: Global AIRS and MOPITT CO measurements: Validation, comparison, and links to biomass burning variations and carbon cycle, J. Geophys. Res., 113, D09301, doi:10.1029/2007JD009229, 2008.

Zhang, L., Jacob, D. J., Boersma, K. F., Jaffe, D. A., Olson, J. R., Bowman, K. W., Worden, J. R., Thompson, A. M., Avery, M. A., Cohen, R. C., Dibb, J. E., Flock, F. M., Fuelberg, H. E., Huey, L. G., McMillan, W. W., Singh, H. B., and Weinheimer, A. J.: Transpacific transport of ozone pollution and the effect of recent Asian emission increases on air quality in North America: an integrated analysis using satellite, aircraft, ozonesonde, and surface observations, Atmos. Chem. Phys., 8, 6117-6136, 2008, http://www.atmos-chem-phys.net/8/6117/2008/. 